\title{
Foraminiferal distribution in the western Barents Sea, Recent and Quaternary
}

\author{
By Kirsten L. Østby ${ }^{1}$ and Jenö Nagy²
}

\begin{abstract}
Foraminiferal faunas were analysed from 22 cores (length $30-165 \mathrm{~cm}$ ), three grab samples and one dredge sample taken from Spitsbergenbanken and the trenches Storfjordrenna and Bjornoyrenna. The distribution pattern of selected taxa and eight assemblages are discussed in relation to water depth, currents and sedimentation. The assemblages found on Spitsbergenbanken where currents are particularly active, are clearly different from the assemblages occurring in the more quiet environments of the trenches.

In the Quaternary evolution of the area three successive stages are distinguished: glacial shelf environment of the Weichselian; semiglacial, or transitional environment of the Late Weichselian and Early Holocene; open, or deglaciated shelf environment of the Holocene. Minor faunal changes in Storfjordrenna are explained by changes in the current pattern.

In some assemblages marked postmortem changes have taken place which include solution of calcareous shells, breakage and abrasion by currents, and transport of shells out of the high energy bank area with assumed redeposition in deeper water.
\end{abstract}

\section{Introduction}

This paper is based on shallow sampling of bottom sediments in the western part of the Barents Sea, in the area between Sørkapp, Hopen and Bjørnøya (Fig. 1). The sampling was carried out during the summer of 1971 by the Norwegian Continental Shelf Institute and the Norwegian Polar Research Institute. A sedimentological study based on the same material has already been carried out by Bjørlykke et al. (1978).

The aim of the present study is: 1) to give a picture of the recent distribution of foraminifera in the western Barents Sea and relate it to present conditions on the shelf; 2) to elucidate the stratigraphy and paleo-environment in the uppermost part of the Quaternary sequence.

\subsection{The investigated material}

The samples were obtained from 26 stations located in the water depth interval $34-332 \mathrm{~m}$. Gravity cores were recovered from muddy sediments at 22 stations. The diameter of the cores was $5.5 \mathrm{~cm}$ and their length varied from

1 Statoil, Box 300, 4001 Stavanger, Norway.

2 Institutt for geologi, Universitetet i Oslo, Box 1047, Blindern, Oslo 3, Norway. 


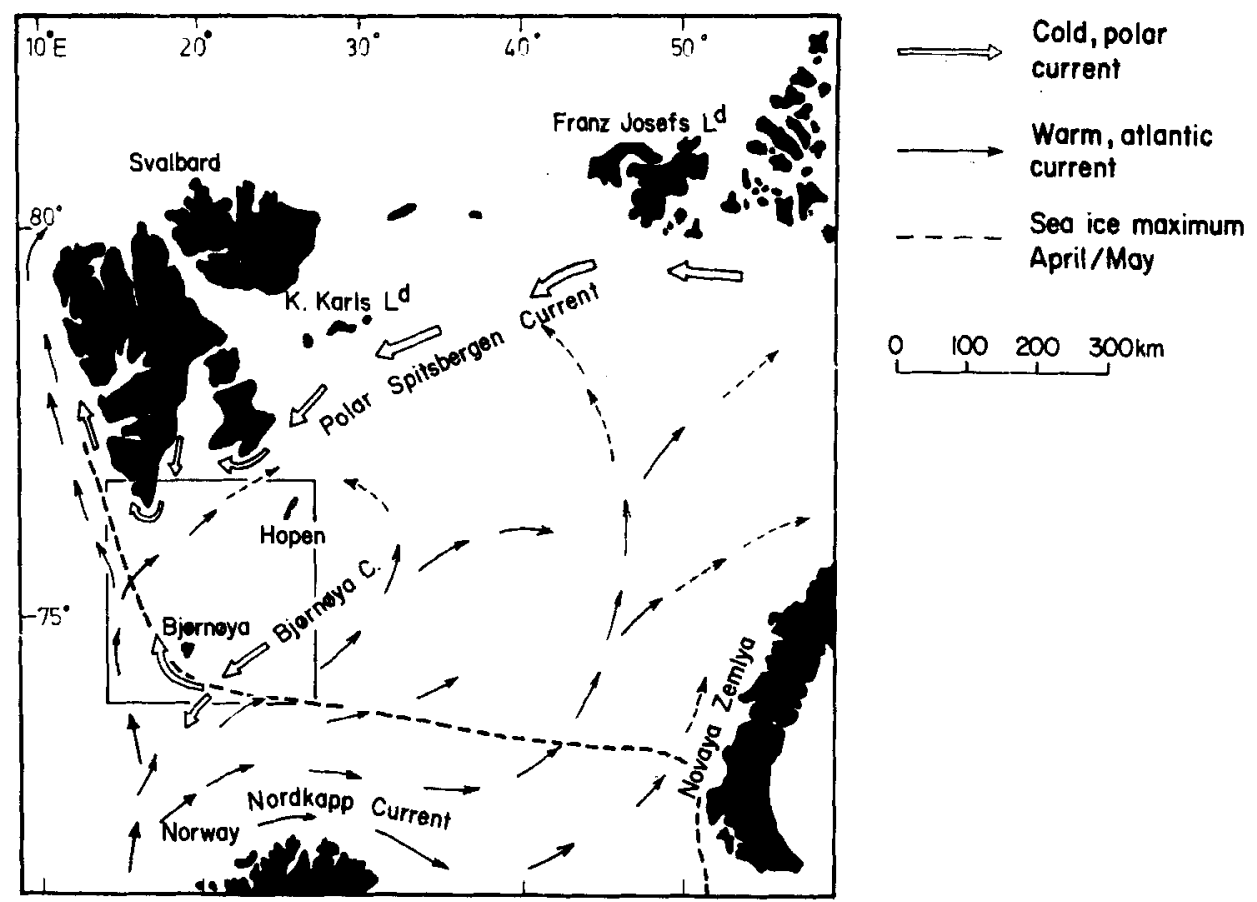

Fig. 1. Map of the Barents Sea showing surface currents and ice distribution. The study area is boxed.

30 to $165 \mathrm{~cm}$. From the most gravelly and sandy parts of Spitsbergenbanken only bulk samples could be taken; by grab at three stations and by dredge at one station. For more details about the sampling see Table 1 and Fig. 2.

\subsection{Laboratory methods}

In the laboratory the samples were treated mainly in accordance with the standard method described by Feyling-Hanssen (1964) and other authors: The dry sample was soaked in a 2-5\% solution of hydrogen peroxide $\left(\mathrm{H}_{2} \mathrm{O}_{2}\right)$ for about 15 minutes and then washed through sieves with mesh diameter 0.1 and $1.0 \mathrm{~mm}$. For the foraminiferal analyses the $0.1-1.0 \mathrm{~mm}$ fraction was used. The shell fraction was concentrated by heavy liquid separation, using a mixture of $\mathrm{CCL}_{4}$ and $\mathrm{CHBr}_{2}$ with a specific gravity of $1.9 \mathrm{~g} / \mathrm{ccm}$.

In many samples the foraminifera showed signs of dissolution. We were aware of the dissolving effect of $\mathrm{H}_{2} \mathrm{O}_{2}$, which can lower the $\mathrm{pH}$ during laboratory disintegration of samples. To clarify this question, four groups of samples were subjected to different treatment: 1) Sediment samples were soaked in $5 \% \mathrm{H}_{2} \mathrm{O}_{2}$. 2) Sediment samples with 0.6 weight $\%$ pyrite added were placed in $5 \% \mathrm{H}_{2} \mathrm{O}_{2}$. (The average pyrite content of the sediments in the area is $0.3 \%$, A. Elverhøi pers. comm.) 3) Shells of five common calcareous and one arenaceous species were placed in $5 \% \mathrm{H}_{2} \mathrm{O}$. 4) The same as group 3 but in $5 \% \mathrm{H}_{2} \mathrm{O}_{2}$ with 1.0 weight $\%$ pyrite equalling about $1 / 3$ of the volume of the foraminifera. 
TABLE 1

List of the sampled stations with position, water depth equipment used, core length, and number of samples analysed from each station.

\begin{tabular}{|c|c|c|c|c|c|c|}
\hline \multirow{2}{*}{$\begin{array}{l}\text { Station } \\
\text { number }\end{array}$} & \multicolumn{2}{|c|}{ Position } & \multirow{2}{*}{$\begin{array}{l}\text { Water } \\
\text { depth } \\
\text { (m) }\end{array}$} & \multirow[b]{2}{*}{ Equipment } & \multirow{2}{*}{$\begin{array}{c}\text { Core } \\
\text { length } \\
\mathrm{cm}\end{array}$} & \multirow{2}{*}{$\begin{array}{c}\text { No of } \\
\text { samples } \\
\text { studied }\end{array}$} \\
\hline & $\begin{array}{c}\mathrm{N} \\
\text { latitude }\end{array}$ & $\begin{array}{c}E \\
\text { longitude }\end{array}$ & & & & \\
\hline 4 & $74^{\circ} 02.9^{\prime}$ & $21^{\circ} 07.9^{\circ}$ & 310 & grav.corer & 150 & 14 \\
\hline 13 & $74^{\circ} 21.4^{\prime}$ & $24^{\circ} 15.0^{\circ}$ & 298 & $-"-$ & 40 & 4 \\
\hline 16 & $74^{\circ} 22.7^{\prime}$ & $22^{\circ} 05.0^{\circ}$ & 196 & $-"-$ & 40 & 4 \\
\hline 57 & $74^{\circ} 59.3^{\prime}$ & $22^{\circ} 28.5^{\prime}$ & 82 & $-" n-$ & 45 & 2 \\
\hline 66 & $75^{\circ} 04.9^{\prime}$ & $17^{\circ} 48.1$ ' & 105 & $-" \quad-$ & 38 & 4 \\
\hline 72 & $75^{\circ} 26.3^{\prime}$ & $21^{\circ} 29.0^{\prime}$ & 34 & grab & - & 1 \\
\hline 85 & $75^{\circ} 32.3^{\prime}$ & $20^{\circ} 02.4^{\prime}$ & 73 & grav.corer & 80 & 3 \\
\hline 90 & $75^{\circ} 34.1^{\prime}$ & $18^{\circ} 23.4^{\prime}$ & 124 & $-"-$ & 40 & 2 \\
\hline 91 & $75^{\circ} 37.7^{\prime}$ & $19^{\circ} 18.1$ & 88 & $-" 1-$ & 30 & 2 \\
\hline 96 & $75^{\circ} 51.7^{\prime}$ & $22^{\circ} 19.0^{\prime}$ & 46 & dredge & - & 1 \\
\hline 99 & $75^{\circ} 59.2^{\prime}$ & $24^{\circ} 32.5^{\prime}$ & 70 & grab & - & 1 \\
\hline 102 & $76^{\circ} 14.5^{\prime}$ & $24^{\circ} 02.0^{\prime}$ & 55 & $-" 1-$ & - & 1 \\
\hline 109 & $76^{\circ} 26.9^{\prime}$ & $23^{\circ} 11.9^{\prime}$ & 104 & grav.corer & 90 & 3 \\
\hline 115 & $76^{\circ} 27.4^{\prime}$ & $22^{\circ} 35.0^{\prime}$ & 176 & $-"-$ & 110 & 5 \\
\hline 116 & $76^{\circ} 23.8^{\prime}$ & $21^{\circ} 58.8^{\prime}$ & 152 & $-"=$ & 100 & 4 \\
\hline 126 & $75^{\circ} 40.2^{\prime}$ & $17^{\circ} 39.9^{\prime}$ & 192 & $-"-$ & 30 & 2 \\
\hline 132 & $76^{\circ} 04.8^{\prime}$ & $20^{\circ} 12.7^{\prime}$ & 142 & $-" 1-$ & 110 & 4 \\
\hline 139 & $76^{\circ} 32.8^{\prime}$ & $20^{\circ} 14.1^{\prime}$ & 182 & - " & 100 & 6 \\
\hline 147 & $76^{\circ} 06.2^{\prime}$ & $18^{\circ} 53.0^{\prime}$ & 195 & - " - & 38 & 2 \\
\hline 152 & $76^{\circ} 25.7^{\prime}$ & $17^{\circ} 47.8^{\prime}$ & 215 & $-"-$ & 100 & 6 \\
\hline 154 & $76^{\circ} 06.0$ & $17^{\circ} 26.0^{\circ}$ & 290 & $-" 1-$ & 85 & 5 \\
\hline 155 & $75^{\circ} 55.4^{\prime}$ & $17^{\circ} 06.7^{\prime}$ & 306 & $-"-$ & 110 & 6 \\
\hline 156 & $75^{\circ} 52.8^{\prime}$ & $16^{\circ} 24.0^{\prime}$ & 332 & $-" 1-$ & 110 & 7 \\
\hline 163 & $76^{\circ} 43.7^{\prime}$ & $18^{\circ} 10.0^{\circ}$ & 200 & $-"-$ & 90 & 5 \\
\hline 166 & $76^{\circ} 52.2^{\prime}$ & $20^{\circ} 08.2^{\prime}$ & 132 & $-"-$ & 115 & 8 \\
\hline 169 & $76^{\circ} 29.8^{\prime}$ & $21^{\circ} 27.1^{\prime}$ & 218 & $="-$ & 165 & 7 \\
\hline
\end{tabular}




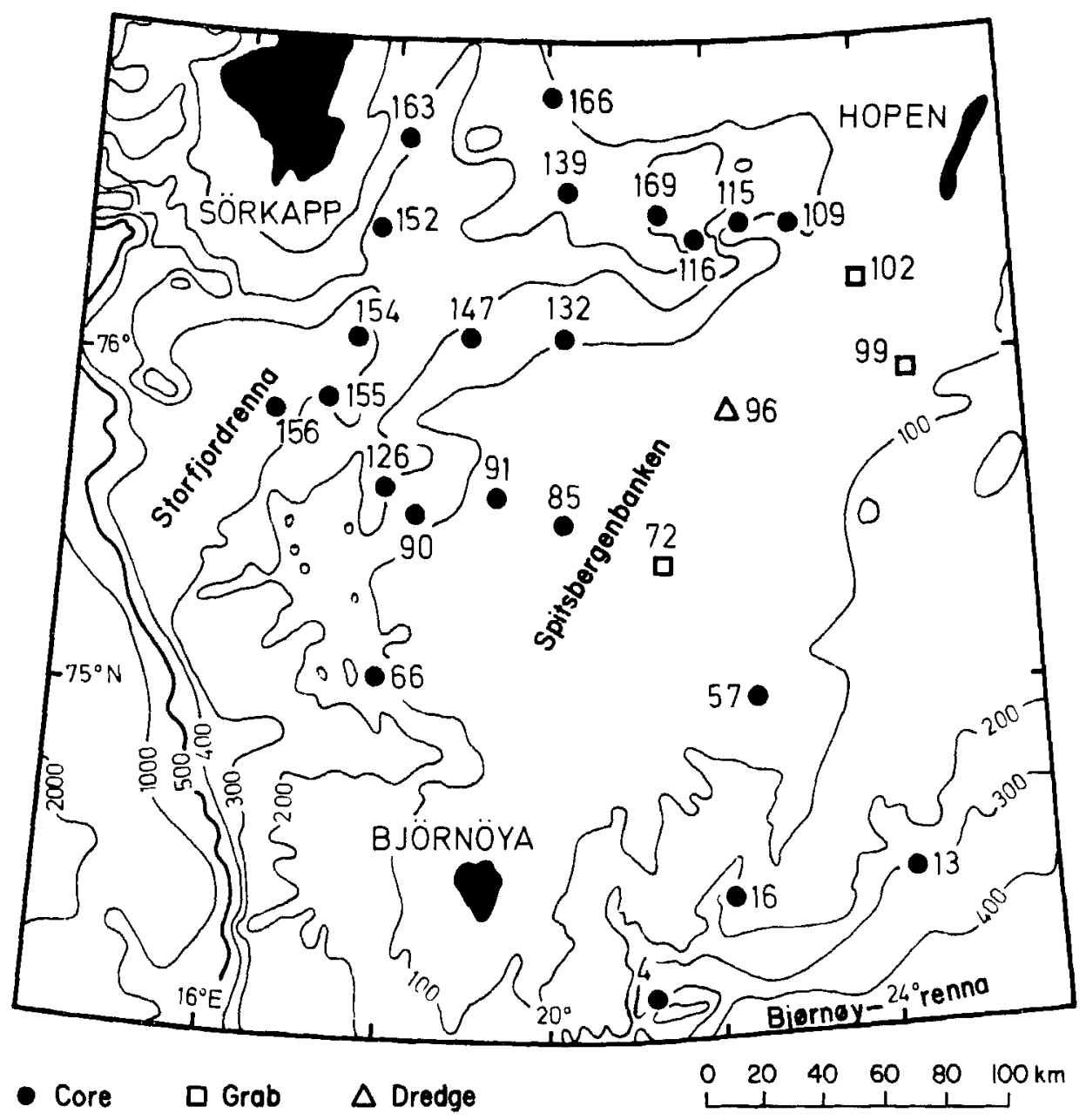

Fig. 2. Bathymetric map of Spilsbergenbanken and surrounding areas showing location of the sampling stations.

Three sets of samples from each group were soaked in the solutions, for 15 minutes, 2 hours, and 16 hours, respectively. The calcareous species showed no traces of etching after this treatment. The arenaceous Adercotryma glomeratum, however, had its last formed chambers dissolved after 15 minutes in $\mathrm{H}_{2} \mathrm{O}_{2}$ with pyrite, while its whole shell had become fragile after 16 hours in the same solution.

Based on these observations we may conclude that the disintegration method has no visible dissolution effect on calcareous shells, but some arenaceous shells may possibly be damaged in samples with extremely high pyrite content.

\subsection{Faunal parameters}

The faunal diversities were calculated in accordance with Walton (1964), and the Fisher $a$ indices are given after the graphic method of Murray (1973). On the range charts adjacent samples are compared by similarity indices des- 
scribed by Sanders (1960). The proportion of planktonic foraminifera is measured by the percentage of planktonic + benthonic shells. The percentage of benthonic species is calculated from the total benthonic assemblage.

\section{The regional background}

\subsection{Topography and geology}

The investigated area is Spitsbergenbanken with its bordering trenches Storfjordrenna and Bjørnøyrenna. This topographical tripartition is reflected in the distribution pattern of both the sediments and foraminifera. Most of Spitsbergenbanken is shallower than $100 \mathrm{~m}$, with water depths mainly between $30 \mathrm{~m}$ off Bjørnøya and $80 \mathrm{~m}$ near Hopen. Storfjordrenna separates the bank from the shallow areas around Spitsbergen, and has depths of $200-400 \mathrm{~m}$ in its axial parts. Bjørnøyrenna reaches depths around $450 \mathrm{~m}$ before it opens onto the continental slope.

It is evident from recent marine geophysical and geological studies combined with glacial geological investigations (e.g. Hoppe 1970, Matisov 1977, Elverhøi and Kristoffersen 1978, Boulton 1979) that the Barents Sea was extensively glaciated during the Pleistocene. However, the age and number of glacial periods and the regional extent of the ice-sheets are still open questions. Several arguments for the occurrence of an extensive Weichselian ice-sheet in the northern and western Barents Sea are given by Hoppe (1970).

The surface sediments on Spitsbergenbanken and its slopes are divided into the following four regional facies (Bjørlykke et al. 1978): 1) Lag deposits covering the shallowest parts of the bank at depths of $30-80 \mathrm{~m}$. These sediments consist of Mesozoic gravel and sand that have been eroded from underlying till or bedrock, and of bioclastic carbonate sand and gravel consisting mainly of bivalves and cirripeds. 2) Upper slope facies of sandy mud (Holocene). Its transition to the lag deposits represents the lower limit of active erosion located at about $100 \mathrm{~m}$ water depth on the western side of the bank and at about $70 \mathrm{~m}$ on the eastern side. 3) Fine-grained mud (Holocene) on the deeper parts of the trenches at $150-400 \mathrm{~m}$. 4) Glacial clay (till) from the Pleistocene exposed on the south-eastern slope of the bank.

\subsection{Water masses}

The current pattern in the Barents Sea is controlled by the position of the shelf between the Arctic and Atlantic ocean basins (Fig 1). Warm, Atlantic water is transported into the Barents Sea between Bjørnøya and Nordkapp by a branch of the North Atlantic Current. A smaller branch of the same current flows onto the shelf through Storfjordrenna. These warm currents give positive bottom temperatures in the western parts of the Barents Sea. The bottom temperature in Bjørnøyrenna may reach $5^{\circ} \mathrm{C}$ (April), and in Storfjordrenna $2^{\circ} \mathrm{C}$ (June). Farther east on the shelf the bottom temperature falls to $-2^{\circ} \mathrm{C}$. The salinity of Atlantic water is around $34.9 \%$ at the bottom of Storfjordrenna and over $35 \%$ at the bottom of Bjørnøyrenna. 


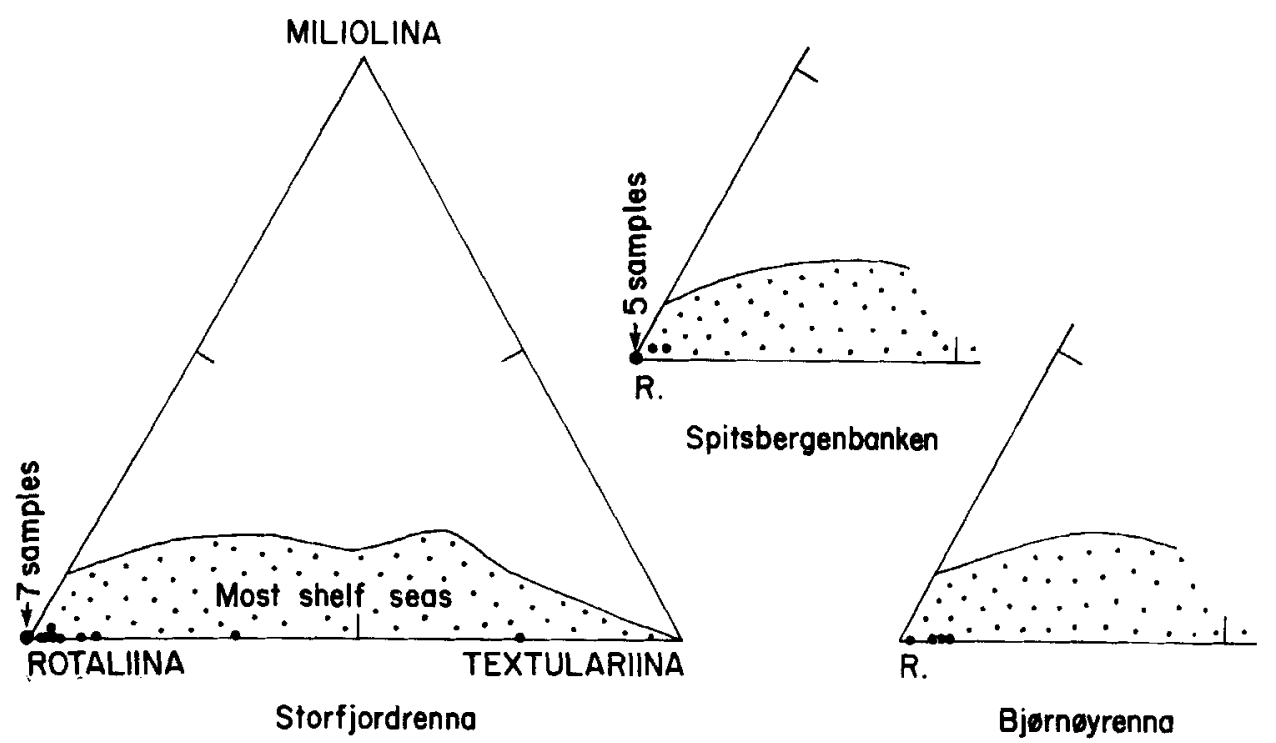

Fig. 3. Triangular plot of surface samples showing the frequency of three suborders of foraminifera in the benthonic assemblage.

Two main currents transporting cold, Arctic water are present in the study area: The Polar Spitsbergen Current with temperatures belov $0^{\circ} \mathrm{C}$ flows westwards south of Edgeøya and Spitsbergen, transporting much sea ice. West of Sørkapp the current turns northwards. The Bjørnøya Current flows along the southeastern slope of Spitsbergenbanken producing negative bottom temperatures and turns northwards west of Bjørnøya.

The conditions on Spitsbergenbanken are characterized by high energy capable of eroding sediment in water depth down to $60-80 \mathrm{~m}$ (Bjørlykke et al. 1978). This is deeper than the normal wave base and the erosion must be caused by high current velocities and probably also by storm surges.

Bjørnøyrenna is mainly free of ice throughout the year. The sea ice has its maximum extension in April-May when it often reaches the area south of Bjørnøya. The ice cover is least in August-September when the entire area between Spitsbergen, Hopen and Bjørnøya is generally ice-free.

\section{Main faunal features in surface sediments}

\subsection{Distribution of suborders and diversity}

The dominant suborder in the area is Rotaliina comprising $98-100 \%$ of the benthonic assemblage at the majority of the stations. Textulariina occurs in larger quantities only at four stations in Storfjordrenna, while Miliolina is very rare in the whole area with frequencies usually below $1 \%$ (Fig. 3). Fisher $\alpha$ indices vary between 4 and 11 (Fig. 4). Both the relative frequency of 


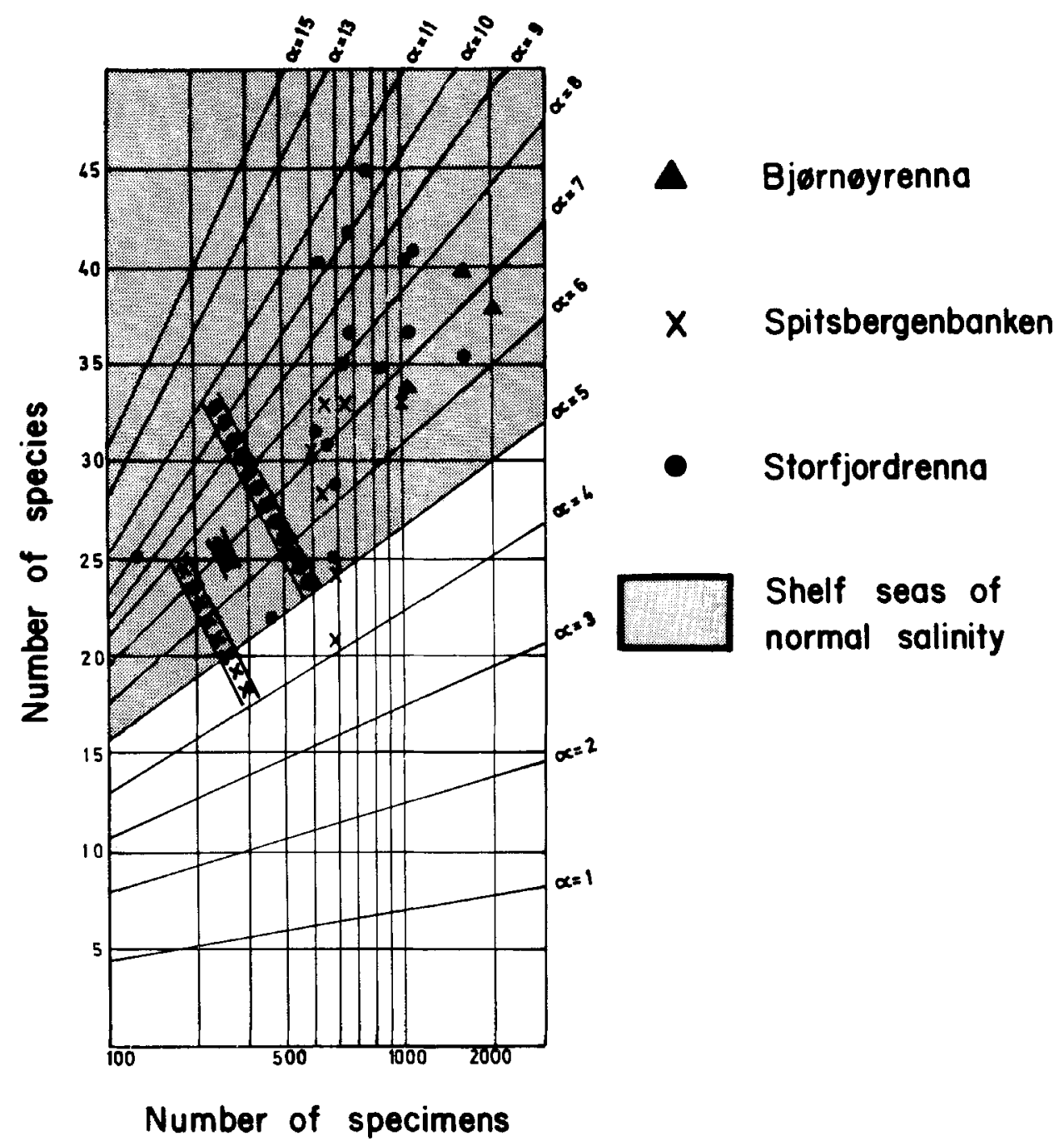

Fig. 4. Diagram showing the benthonic diversity in surface samples expressed by Fisher $\alpha$ indices.

the suborders and the $\alpha$ values, except at one station, are within the range defined for shelf seas by Murray (1973).

The lowest $\alpha$ values $(4-8)$ are found on Spitsbergenbanken, while highest values $(5-11)$ are observed in Storfjordrenna.

\subsection{Number of species and specimens}

In the analysed samples a total of 218 species (inclusive a few subspecies) are found, about 160 of which occur in the surface sediments. The number of species per surface sample varies from 22 to 64 (Fig. 11). The twelve most common species constitute approximately $87 \%$ of the total benthonic fauna of the area. These species, listed in decreasing abundance are as follows: Cassidulina crassa, Cibicides lobalulus, Elphidium excavatum, Cassidulina 
laevigata, Islandiella norcrossi, Nonion labradoricum, Adercotryma glomeratum, Astrononion gallowayi, Buccella frigida, Elphidium frigidum, Nonion barleeanum, Trifarina fluens. The three most common species occur in nearly all samples.

The quantity of foraminiferal shells per unit surface sediment (Fig. 5) attains maximum values on Spitsbergenbanken in spite of the effect of strong abrasion and breakage together with transport of shells out of the bank area. (For a discussion of these factors see chapter 7.) The foraminiferal content of the sediment on Spitsbergenbanken varies from 1300 to 8400 shells per gram of sediment except for one station with 580 . The high values are most probably caused by strongly restricted deposition of terrigene clastics on the bank. High organic production on the bank increases both the number of foraminifera and the amount of other biogenic carbonate (which is the dominant sediment component in shallower areas).

In Bjørnøyrenna and Storfjordrenna the foraminiferal content of the sediment is 11 to 410 shells per gram. These relatively low concentrations must be attributed to increased sedimentation rates, mainly of clay and silt.

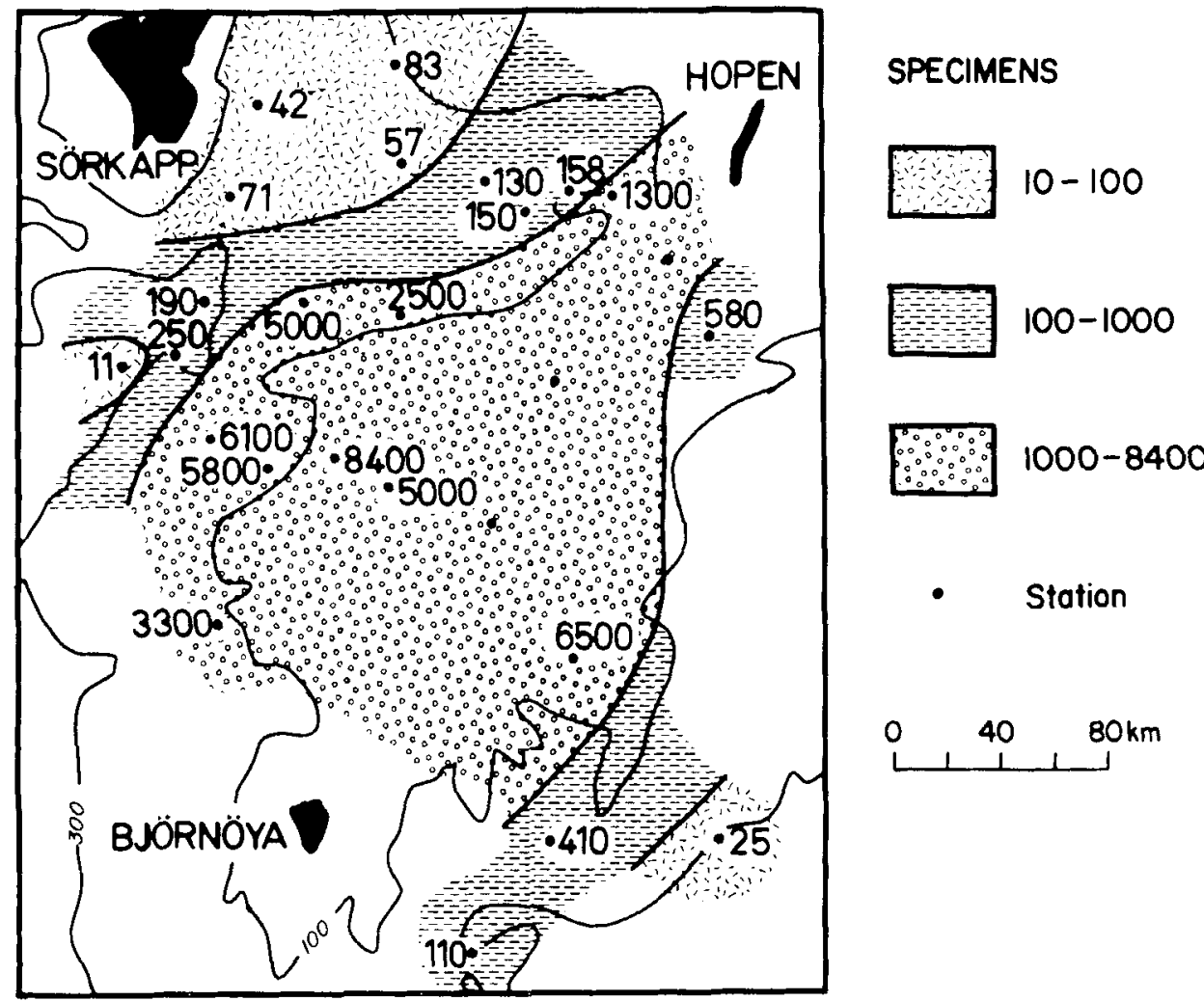

Fig. 5. Distribution of foraminiferal shells in the surface sediments, shown as number of specimens per gram sediment. 


\section{Selected taxa in surface sediments}

\subsection{Distribution of Textulariina}

On Spitsbergenbanken arenaceous foraminifera comprise only $0-1 \%$ of the benthonic assemblage (Fig. 6), except for one station where the group occurs with $5 \%$. In Bjørnøyrenna arenaceous species comprise up to $3 \%$ in the east and $1 \%$ in the west and are present down to a depth of $30-40 \mathrm{~cm}$ in the cores.

Comparatively large concentrations of Textulariina are found in the central and northern parts of Storfjordrenna where the highest frequencies are 10 and $31 \%$. This increase is probably due to low temperature combined with a finegrained substrate.

A maximum of $70 \%$ of arenaceous foraminifera is found at station 156 (depth $332 \mathrm{~m}$ ) in the outer part of Storf jordrenna. This maximum is thought to have resulted from the dissolution of calcareous shells combined with low temperatures and very fine substrate. The effect of dissolution is indicated by the presence of strongly corroded calcareous shells, and the near total absence of planktonic species which are common farther east, at shallower stations in the trench.

In this connection it must be noted that in the axial part of the trench,

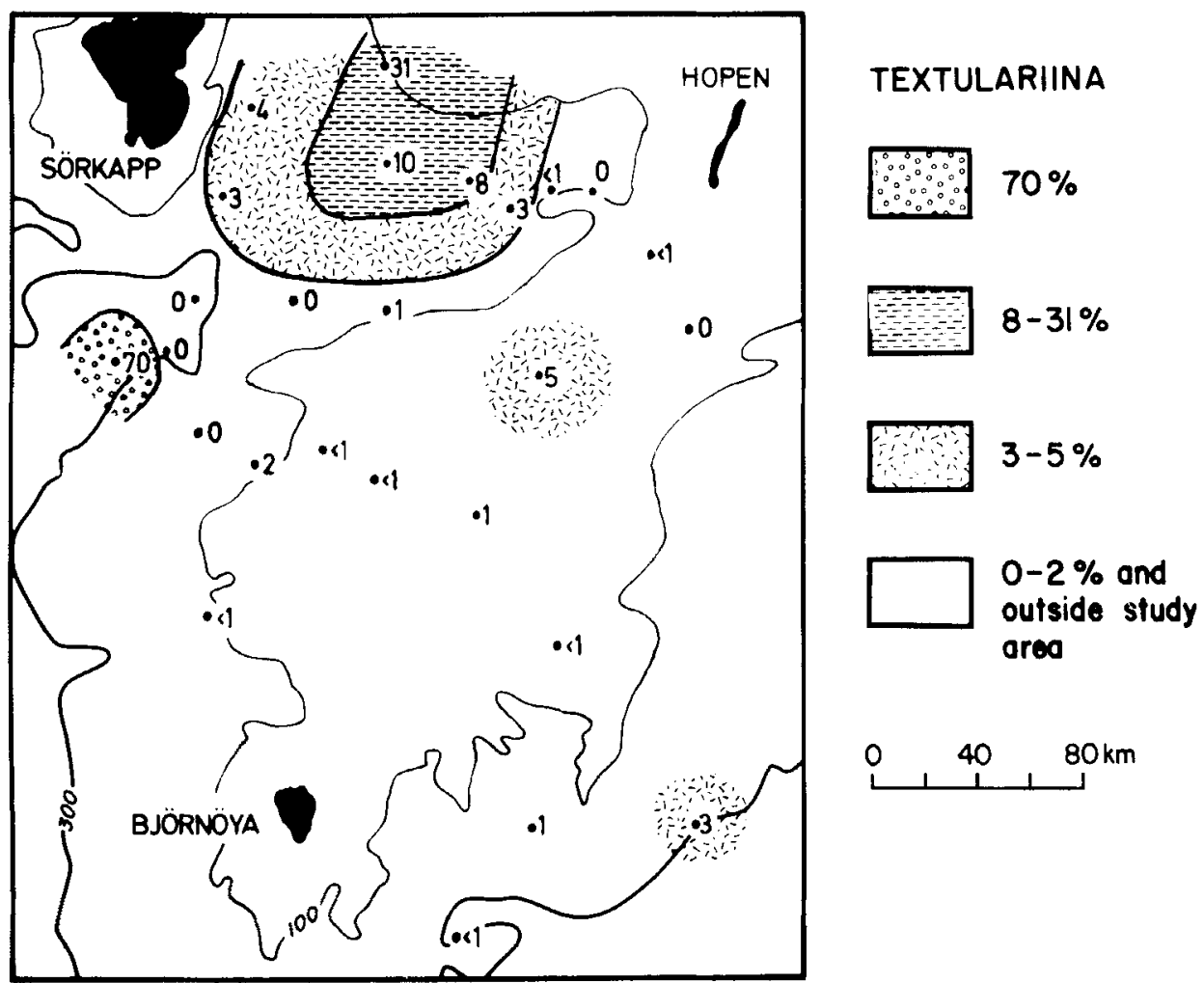

Fig. 6. Distribution of the suborder Textulariina in the surface sediments. 
extremely low temperatures $\left(<-1{ }^{\circ} \mathrm{C}\right)$ and high salinities $(>35 \% 00$ were measured. According to Ljøen (pers. comm.) these values belong to water masses which formed on the shelf during the winter, and flow out along the floor of the trench.

The rich arenaceous assemblage at station 156 prevails down to a core depth of $90 \mathrm{~cm}$, below which it is reduced to a few scattered specimens. This reduction may probably be ascribed to diagenetic destruction of arenaceous shells in the sediment.

\subsection{Distribution of planktonic foraminifera}

The amount of planktonic foraminiferal shells in the northern part of the area generally increases with increasing depth and is correlative with the current pattern. On Spitsbergenbanken the frequency of the group is 0 to less than $1 \%$. On the northern slope of the bank the frequency increases, and reaches a maximum of $14 \%$ at a depth of $306 \mathrm{~m}$ in Storfjordrenna. In this trench the distribution of the group is clearly related to the inflowing current of Atlantic water (Fig. 7). On the northern flank of the trench the amount of planktonic shells is smaller than at similar depths on the southern flank. This reduction seems to be caused by the southwest flowing Polar Spitsbergen Current which affects the area just south of Storfjorden and Spitsbergen.
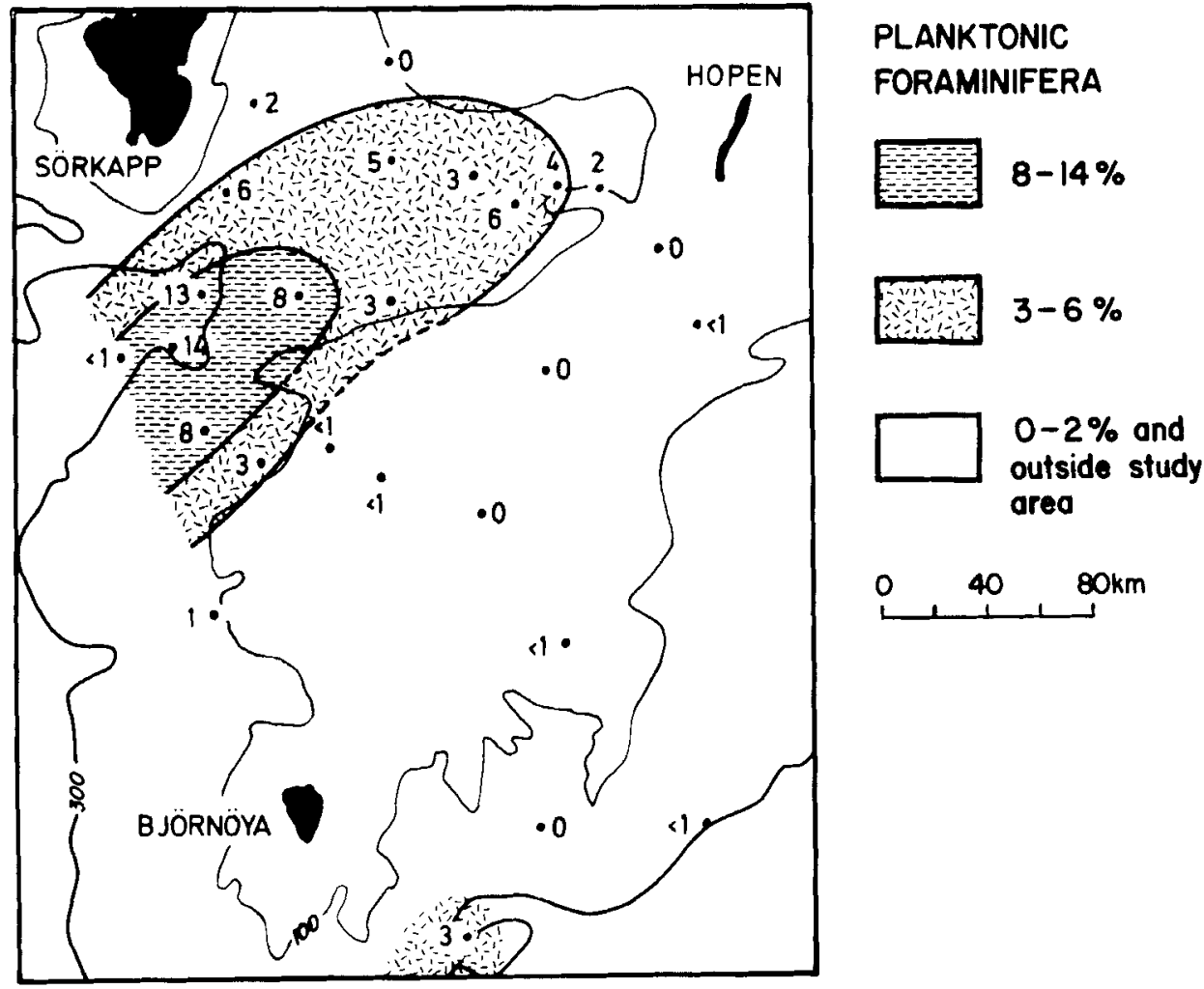

Fig. 7. Distribution of planktonic foraminifera in the surface sediments. 
In the southern part of Bjørnøyrenna the frequency of planktonic shells reaches $49 \%$ (Jarke 1960), while on its northern flank only $0-3 \%$ are observed. These small amounts on the northern flank can be attributed to the Bjørnøya Current transporting Arctic water towards the southwest.

The quantitatively most important planktonic species in the study area are: the Arctic and Subarctic Globoquadrina pachyderma, Globigerina quinqueloba, and Globigerina bulloides; the more temperate Globigerinita glutinata and Globoquadrina dutertrei. A general featur of the area is that in all samples where Textulariina constitutes $20 \%$ or more, the planktonic assemblage is reduced to $0-1 \%$. Similar conditions were also found by Jarke (1960) farther south in the Barents Sea.

\subsection{Distribution of Cibicides lobatulus}

Sibicides lobatulus is generally regarded as a cosmopolitan, attached, inner shelf species, most common on sand or gravel bottom in areas with strong current activity. This is in good agrement with the distribution of the species in the present study area.

In the high energy environment of Spitsbergenbanken $C$. lobatulus constitutes $40-68 \%$ of the benthonic fauna (Fig. 8). On the flanks of the bank the grain

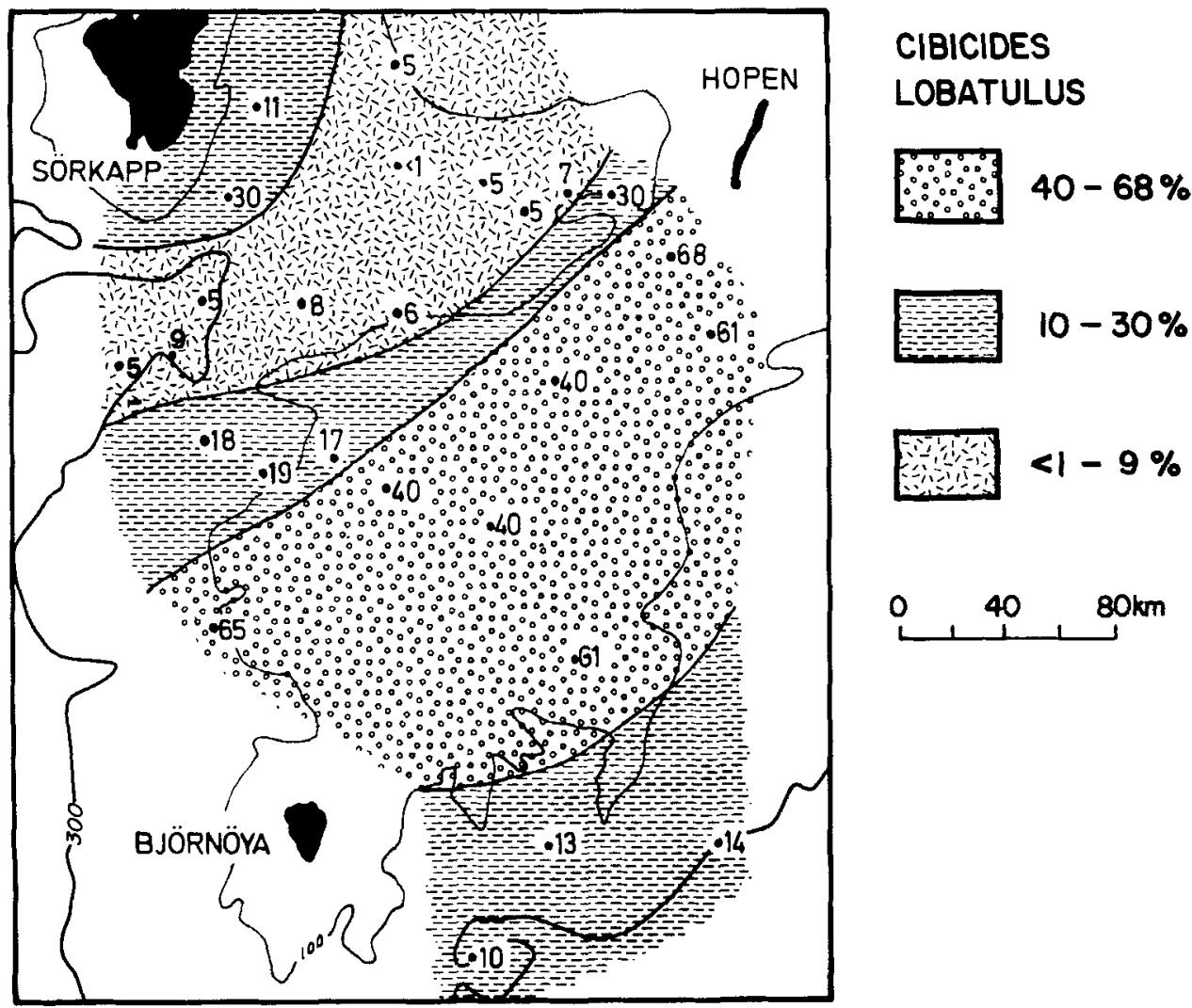

Fig. 8. Distribution of Cibicides lobatulus in the surface sediments. 
size of the sediment and the frequency of $C$. lobatulus decreases downslope. Low frequencies $(<1-9 \%)$ are found in the central and northeastern part of Storfjordrenna, while on the northwestern flank of the trench in shallower water, again high values (11 and $30 \%$ ) are observed.

\subsection{Distribution of Cassidulina laevigata}

Cassidulina laevigata is most common in Storfjordrenna where its distribution corresponds to inflowing Atlantic water with comparatively high temperatures (Fig. 9). The central area with maximum frequencies $(15-36 \%)$ is located at depths of $146-252 \mathrm{~m}$ which roughly corresponds to bottom temperatures higher than $1^{\circ} \mathrm{C}$. The surrounding area with intermediate frequencies $(4-12 \%)$ is $104-306 \mathrm{~m}$ deep and has bottom temperatures from -1 to $+1{ }^{\circ} \mathrm{C}$. Low frequencies $(0-2 \%)$ are present in areas with temperatures below $0^{\circ} \mathrm{C}$, such as the upper flanks of Storfjordrenna and the northern flank of Bjørnøyrenna.

In recent faunas $C$. laevigata is mainly reported from boreal areas like Oslofjorden, Kattegat, Skagerrak, and the North Sea, where it composes a considerable part (up to $67 \%$ ) of the assemblages (Lange 1956, Jarke 1961, Risdal 1964, Nagy and Ofstad 1980). The species was recently reported from Fugløybanken and Tromsøflaket by Vorren et al. (1978).

Earlier records of C. laevigata from Arctic areas (Goës 1894, Kiær 1899, Cushman 1948) probably included Islandiella norcrossi and Islandiella helenae under this name. Both are true Arctic species (Nørvang 1945, Feyling-Hanssen 1976). In newer publications C. laevigata is rarely or never recorded from Arctic areas (e.g. Locblich and Tappan 1953, Nagy 1965, Sen Gupta 1972). A few specimens of the species are found recently in Kongsfjorden, Spitsbergen, by Elvehøi et al. (1980).

The occurrence of C. laevigata in Storfjordrenna and in Kongsfjorden shows that the species can occur in the Arctic, where it can form large populations which are related to currents transporting warm water from lower latitudes. It seems that temperature is the main controlling factor and the distribution of the species continues up to the polar front.

\subsection{Distribution of Nonion barleeanum}

The frequency of Nonion barleeanum increases with increasing depth (Fig. 10). On Spitsbergenbanken the species constitutes $0-1 \%$ of the fauna. Around a depth of $200 \mathrm{~m}$ it occurs with $2-4 \%$ and at c. $300 \mathrm{~m}$ it is represented by $10-14 \%$. The increase appears to be non-linear but shows a clear trend. The numbers are somewhat higher for Bjørnøyrenna than for Storfjordrenna. A non-linear depth increase of the species was also recorded by Lange (1956) and Jarke (1960). 


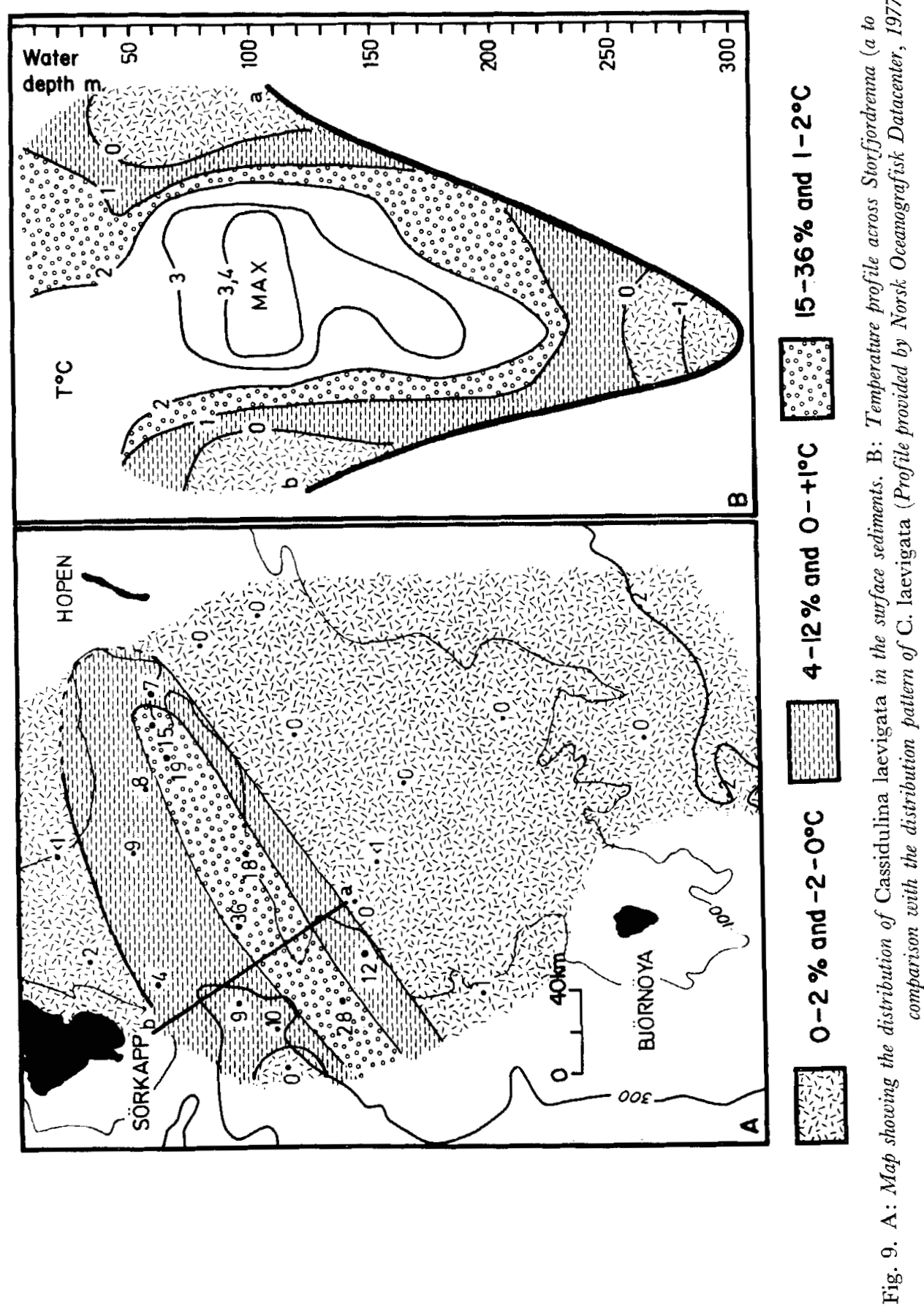




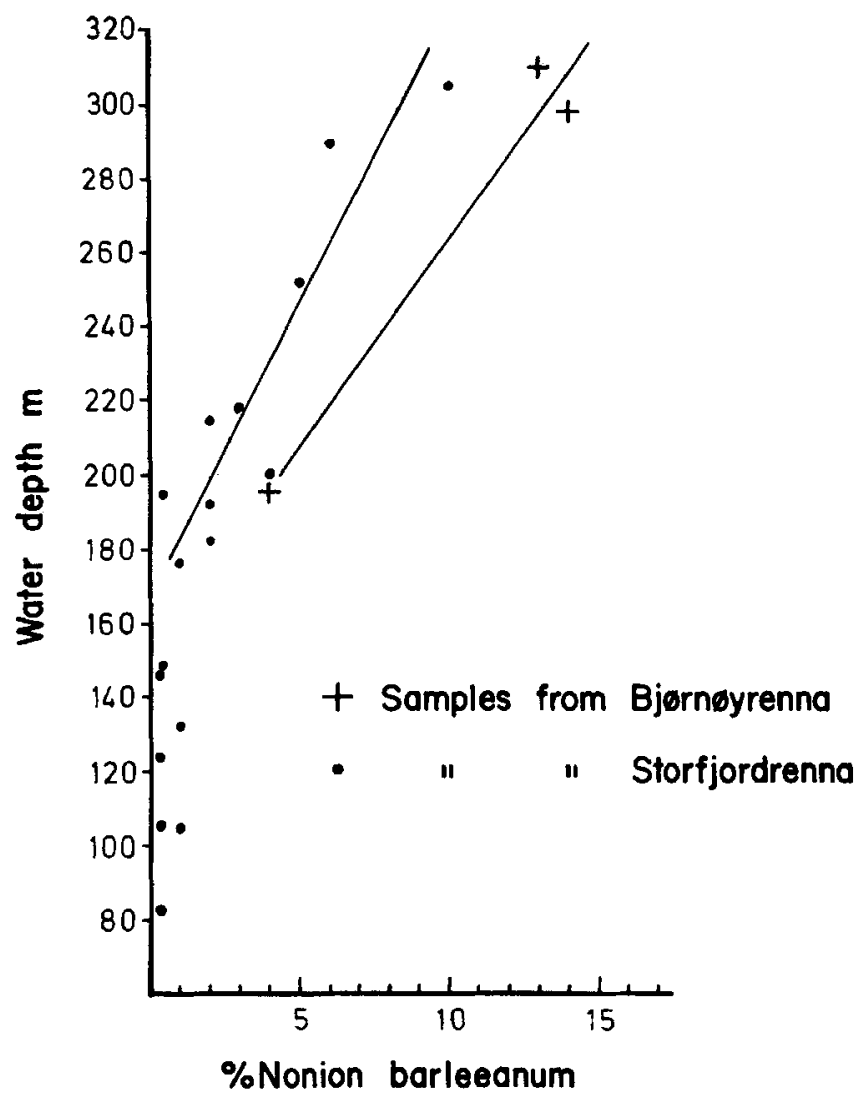

Fig. 10. Graph showing inceasing frequency of Nonion barleeanum with increasing depth.

\section{Composition and distribution of the assemblages}

In the inhomogeneous study area eight foraminiferal assemblages are distinguished. Six of them occur at the bottom surface but are also recognized to varying depths in the cores (Figs. 11 and 15). Two assemblages, the ElphidiumCassidulina and the Nonion-Cassidulina, are found only below the surface of the sea bed. The composition of the assemblages is illustrated by examples in Figs. 12 and 13.

The assemblages are named after the two most common species (Table 2). An exception is the Cibicides-Rosalina assemblage which is dominated by Cibicides lobatulus and Cassidulina crassa while Rosalina spp. is a characteristic part of the assemblage.

The distribution of the assemblages on the bottom surface corresponds in a general way to the topographical tripartition of the area: 1 . Spitsbergenbanken is occupied by the Cibicides-Rosalina assemblage; 2. Bjørnøyrenna contains the Trifarina-Islandiella assemblage; 3. Storfjordrenna is mainly occupied by the Cassidulina-Cassidulina assemblage but contains also three other assemblages. The faunal tripartition is most marked on the bottom surface. The vertical distribution of the assemblages is more varied, particularly in Storfjordrenna. 
TABLE 2

Foraminiferal assemblages, their environments and supposed ages. The assemblages are named after the two most common species (except the Cibicides - Rosalina assemblage which is dominated by Cibicides lobatulus and Cassidulina crassa).

\begin{tabular}{|c|c|c|}
\hline Assemblage & Environment & Supposed age \\
\hline $\begin{array}{l}\text { Cibicides lobatulus } \\
\text { - Rosalina spp. }\end{array}$ & $\begin{array}{l}\text { Open shelf } \\
\text { bank }\end{array}$ & \multirow{4}{*}{ Holocene } \\
\hline $\begin{array}{l}\text { Trifarina fluens } \\
\text { - Islandiella norcrossi }\end{array}$ & \multirow{3}{*}{$\begin{array}{l}\text { Open shelf } \\
\text { trench }\end{array}$} & \\
\hline $\begin{array}{l}\text { Cassidulina laevigata } \\
\text { - Cassidulina crassa }\end{array}$ & & \\
\hline $\begin{array}{l}\text { Adercotryma glomeratum } \\
\text { - Cribrost.crassimargo }\end{array}$ & & \\
\hline $\begin{array}{l}\text { Cassidulina crassa } \\
\text {-Cibicides lobatulus }\end{array}$ & \multirow{3}{*}{$\begin{array}{l}\text { Semiglacial } \\
\text { shelf }\end{array}$} & \multirow{3}{*}{$\begin{array}{l}\text { Late Weichselian- } \\
\text { Early Holocene in } \\
\quad \text { south } \\
\text { Late Weichselian- } \\
\text { Recent in north }\end{array}$} \\
\hline $\begin{array}{l}\text { Adercotryma glomeratum } \\
\text { - Islandiella norcrossi }\end{array}$ & & \\
\hline $\begin{array}{l}\text { Nonion labaradoricum } \\
\text { - Cassidulina crassa }\end{array}$ & & \\
\hline $\begin{array}{l}\text { Elphidium excavatum } \\
\text { - Cassidulina crassa }\end{array}$ & Glacial shelf & Weichselian \\
\hline
\end{tabular}

\subsection{Cibisides-Rosalina assemblage}

The assemblage is dominated by Cibicides lobatulus (40-68\%). Common species are Cassidulina crassa (6-25\%), Astrononion gallowayi (3-20\%), and Elphidium excavatum (1-9\%). Rosalina spp. may account for $15 \%$ of the assemblage. The number of species per sample is $28-48$ and the faunal diversity 7-17. The number of specimens per gram sediment is extremely high, maximum 8400 .

The assemblage occurs in the high energy environment of Spitsbergenbanken where it is recognized to a water depth of $105 \mathrm{~m}$ on the more exposed western slope and to $82 \mathrm{~m}$ in the more sheltered northeastern area. 


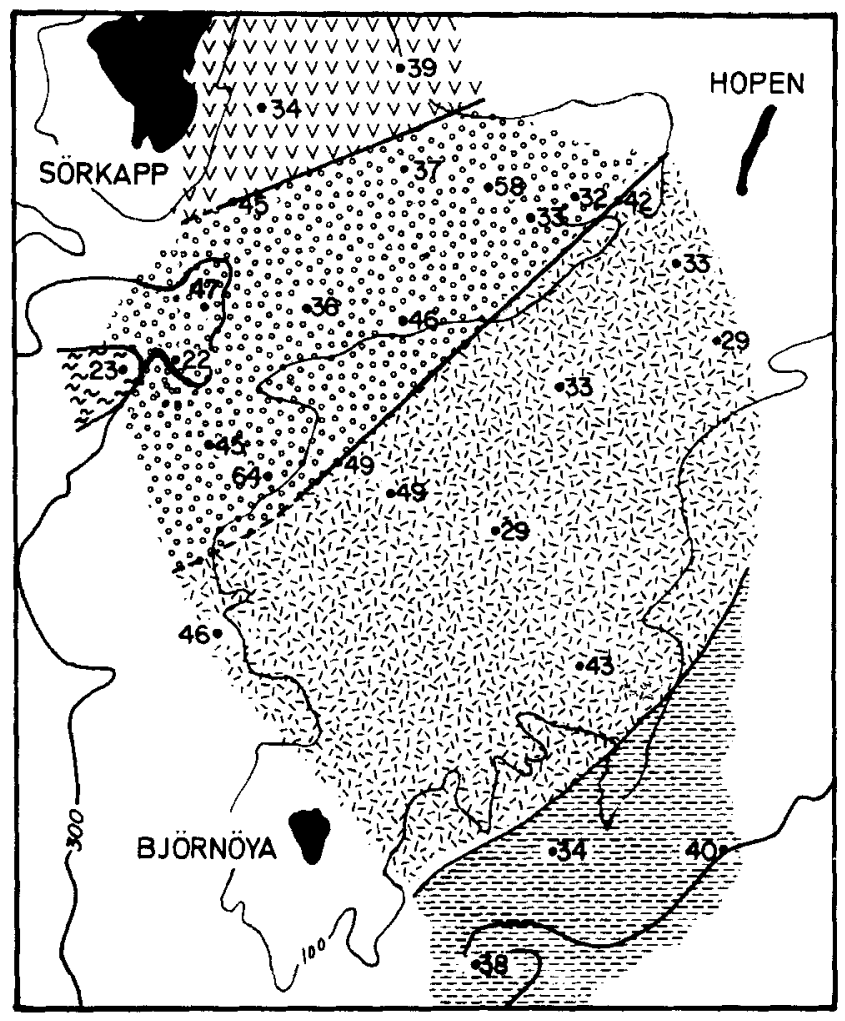

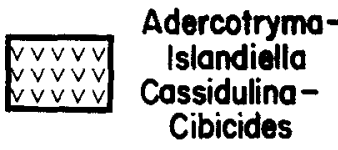

$\because \because \%$ Cassidulina$\because 0 \%$ Cossidulina

\section{$\sim \sim \sim$ Adercotrymo- Cribrostom.}
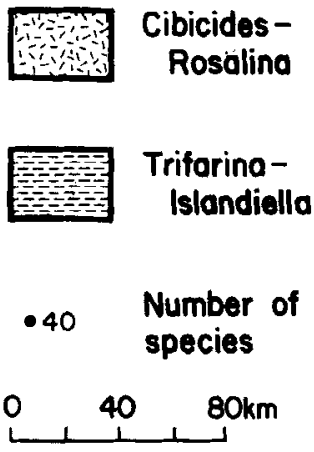

Fig. 11. Surface distribution of benthonic foraminiferal assemblages and number of species in surface samples.

In accordance with the strong current activity the assemblage is dominated by sessile forms, and contains comparatively high numbers of plastogamic species. Sessile forms include: Cibicides lobatulus $(40-48 \%)$, Cyclogyra involvens $(<1 \%)$, Lamarckina haliotidea $(<1 \%)$, Miliolinella subrolunda $(<1-2 \%)$, Patellina corrugata $(<1-3 \%)$, Rosalina spp. $(0-15 \%)$, and Spirillina vivipara $(<1 \%$ ). Plastogamic species include: Glabratella spp. $(<1-10 \%)$, Patellina corrugata, Spirillina vivipara, and probably Rosalina wrightii $(<1-12 \%)$. The amount of miliolid specimens is also relatively high.

As it appears from this account the assemblage found on Spitsbergenbanken reflects the present day environment. According to Bjorlykke et al. (1978) the surface sediments of the bank were partly formed by erosion and reworking of glacial clays. The glacial component occurring in the foraminiferal assemblage may partially have resulted from this erosion, but it may also be entirely of recent and subrecent origin.

\subsection{Trifarina-Islandiella assemblage}

This assemblage is found in the upper part of three cores on the northern side of Bjørnøyrenna. It is dominated by Trifarina fluens (15-20\%), Islandiella norcrossi $(10-16 \%)$, Cibicides lobatulus $(10-14 \%)$, and at a 
depth of $300 \mathrm{~m}$ by $\mathcal{N}$ onion barleeanum (13-14\%). The number of species per sample is $33-40$, the faunal diversity $14-17$, and the number of specimens per gram sediment 25-410.

The species composing this assemblage are common in High Arctic to Sub Arctic regions. The cold nature of the assemblage corresponds to low bottom temperatures produced by the Bjørnøya Current transporting Arctic water along the northern slope of Bjornøyrenna.

\subsection{Cassidulina-Cassidulina assemblage}

The characteristic species of the assemblage is Cassidulina laevigata which dominates together with Cassidulina crassa and Elphidium excavatum. The number of species and specimens is variable but generally high. The faunal diversity is $10-20$ and planktonic species are common.

This assemblage is the most temperate in the study area and occurs on the bottom surface and down to varying core depths in the central and southern parts of Storfjordrenna. The bottom temperatures here are generally higher than $0^{\circ} \mathrm{C}$ and the sediment is clay and silt. The increased bottom temperatures are due to influx of warm, Atlantic water. As mentioned earlier, $C$. laevigata is a boreal species which follows the North Atlantic Current into the Arctic. Other common species of the assemblage are cosmopolitan or Arctic.

\subsection{Cassidulina - Cibicides assemblage}

Towards northwest the Cassidulina-Cassidulina assemblage is replaced by the Cassidulina-Cibicides assemblage, probably because of decreased temperatures. The Cassidulina-Cibicides assemblage is present on the northwestern side of Storfjordrenna, occurring in clay with some gravel and in silty clay. On Spitsbergenbanken and in Bjørnøyrenna the assemblage is recognized below the bottom surface.

The assemblage is dominated by Cibicides lobalulus and Cassidulina crassa. Important species are Elphidium excavatum, Nonion barleeanum and Islandiella norcrossi. The number of species per sample is $9-50$, the faunal diversity 5-16, and the number of specimens per gram sediment maximum 88. Planktonic species attain $5 \%$.

The Cassidulina-Cibicides assemblage is of cold character, but its content of $C$. laevigata (up to $8 \%$ ) and lack of arenaceous species reflect temperatures around $0^{\circ} \mathrm{C}$ (Burmistrova 1967). Relatively rich occurrence of Cibicides lobalulus indicates increased current activity compared to the centre of the trench.

\subsection{Adercolryma - Islandiella assemblage}

Two stations northeast in Storfjordrenna (Nos. 139 and 166) contain this assemblage which is dominated by Adercotryma glomeratum $(7-24 \%)$ and Islandiella norcrossi $(11-21 \%)$. Other important species are Elphidium excavatum (5-25\%), Nonion labradoricum (3-15), and Cassidulina crassa $(7-11 \%)$. The number of species per sample is $36-48$, the faunal diversity 


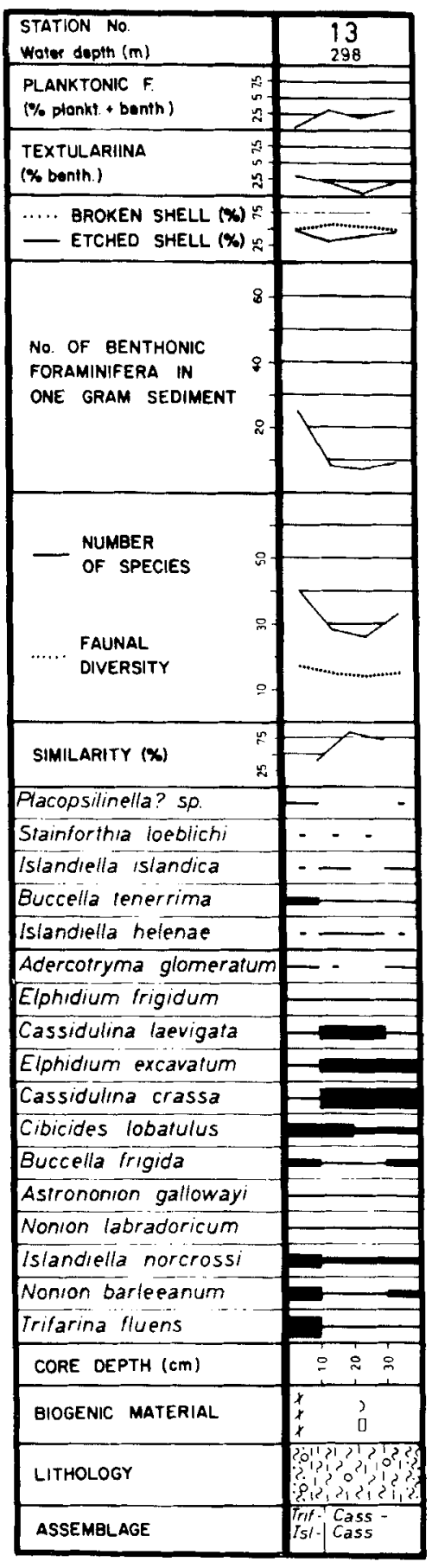

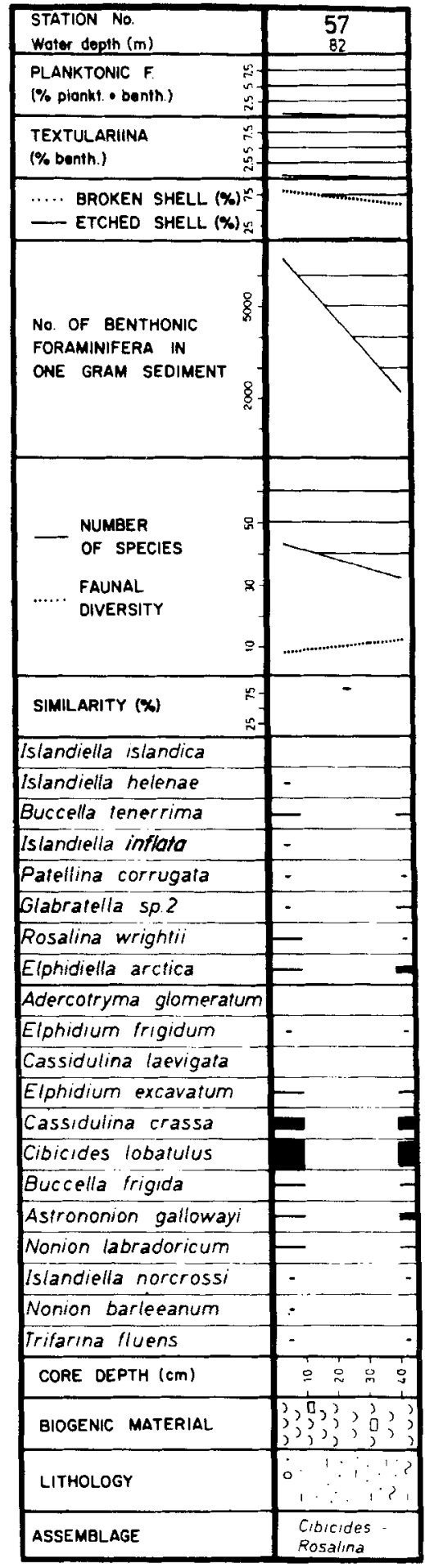




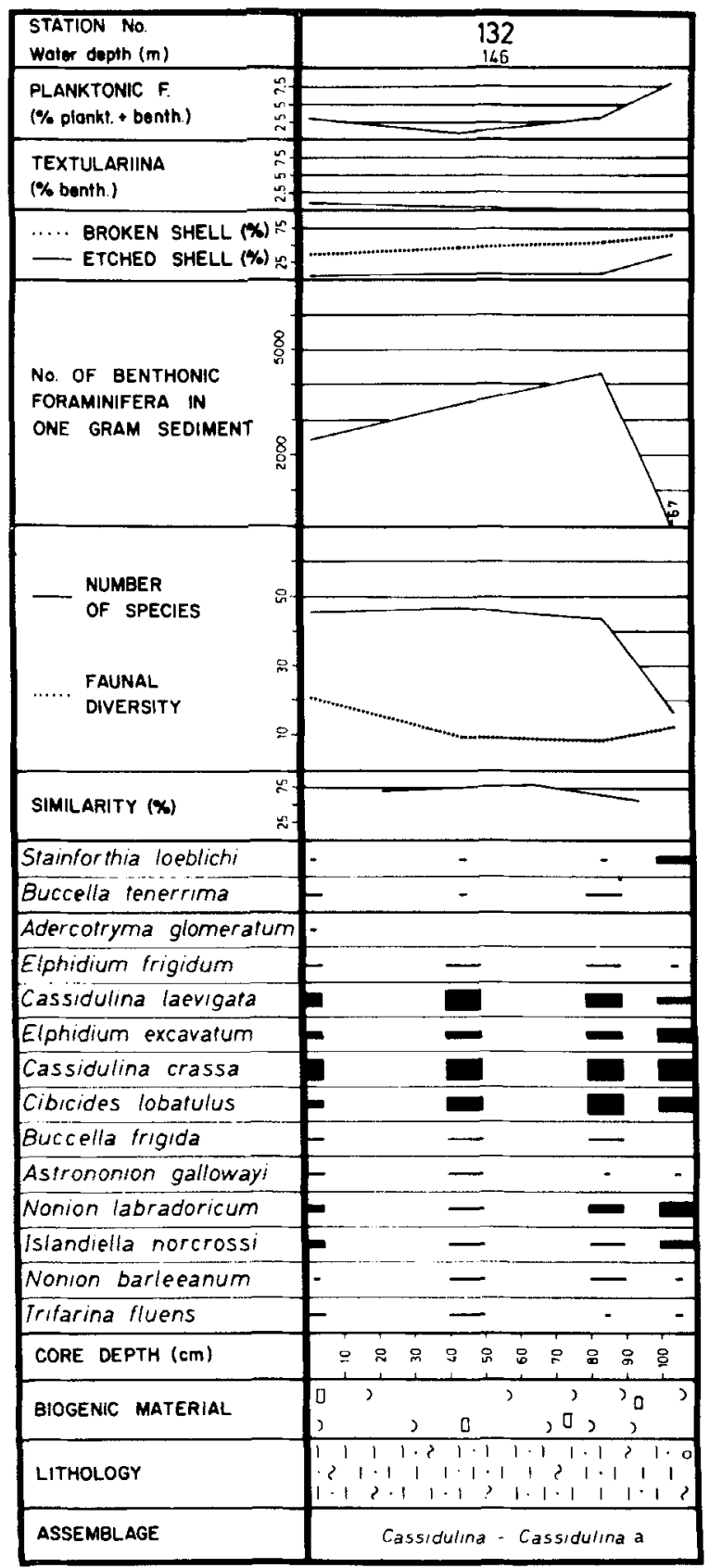

Fig. 12. Range charts of three cores showing distribution of dominant and common species, and different faunal parameters.

(Explanation in Fig. 13.) 


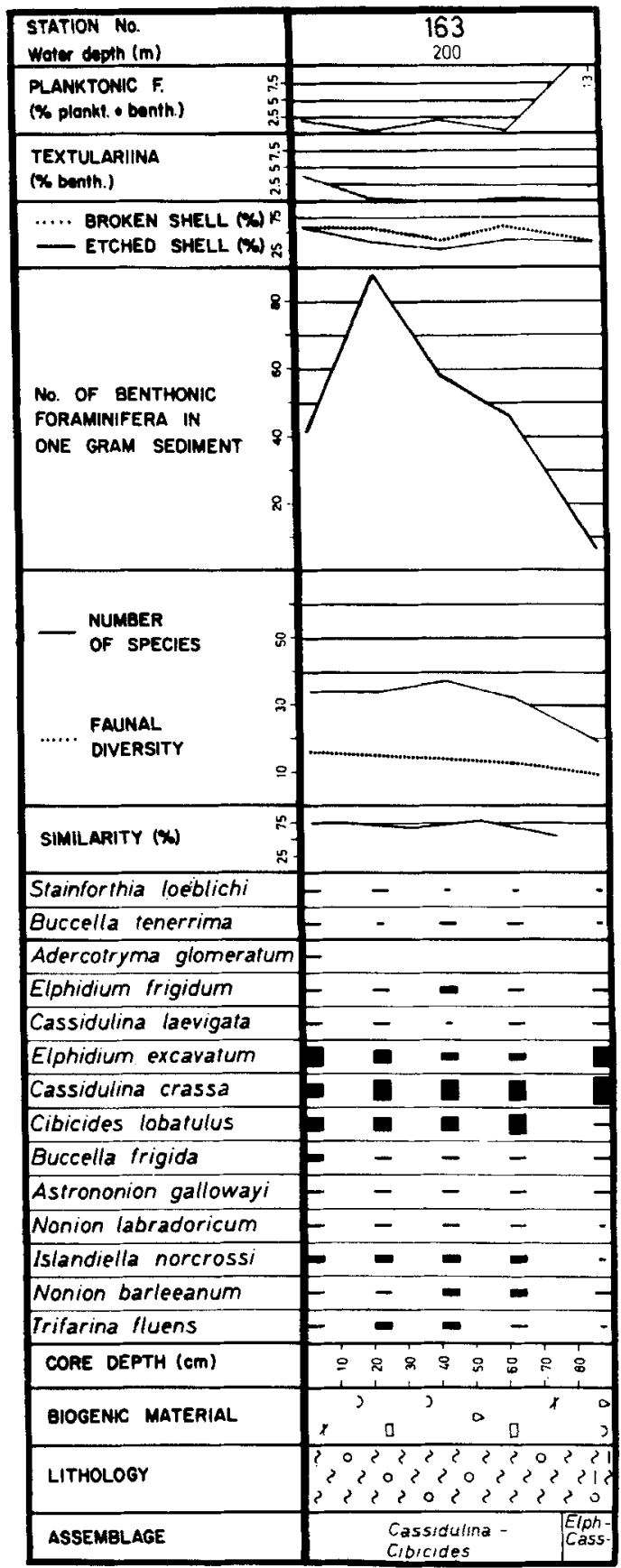

Fig. 13. Range charts of two cores

showing distribution of dominant and common species, and different faunal parameters. 


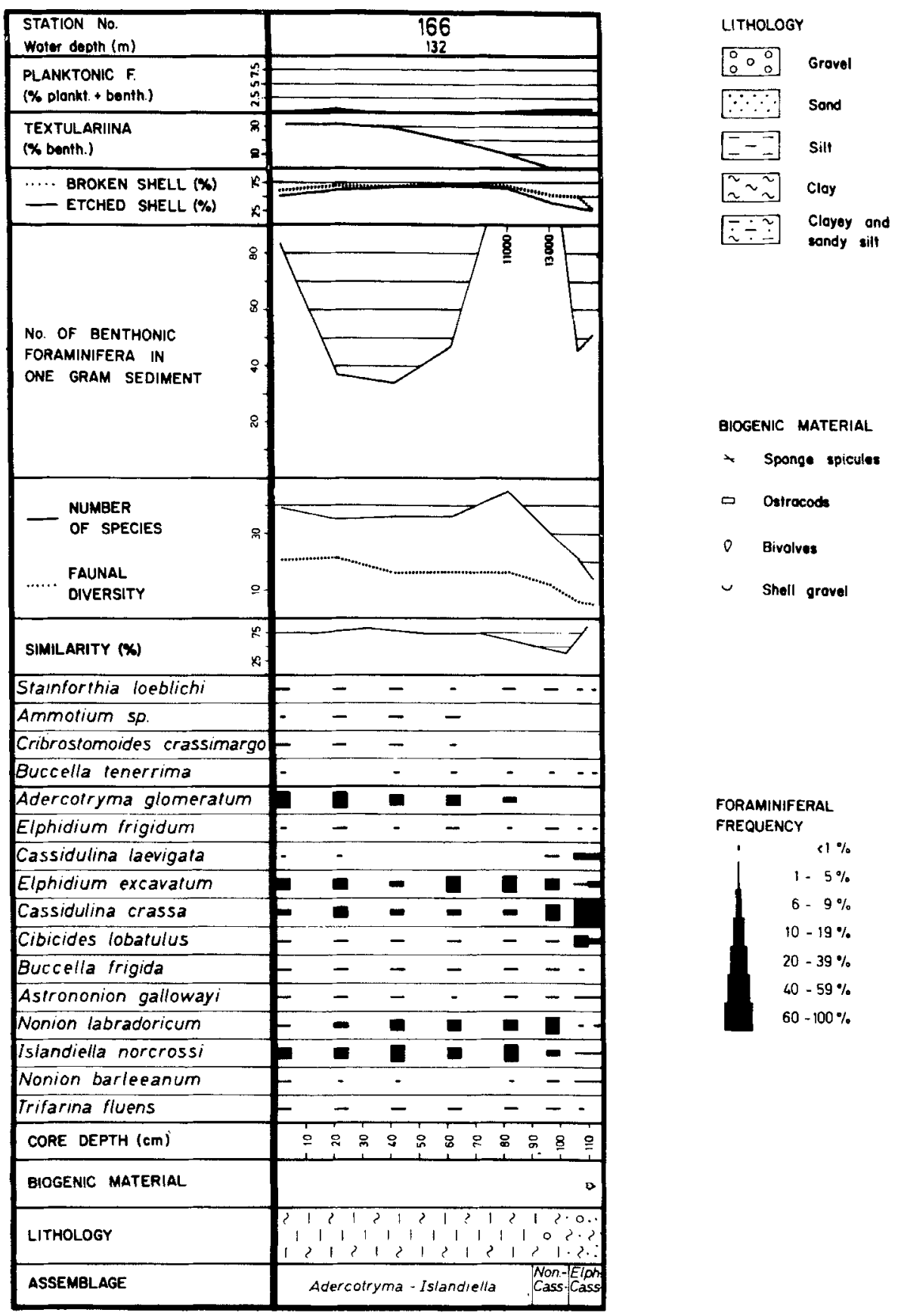


$16-21$, and the number of specimens per gram sediment up to 110 . Arenaceous species compose $10-31 \%$ of the benthonic fauna, and scattered planktonic forms are present. The sediment of the area is clayey silt.

This is a rich, High Arctic assemblage, intermediate between a purely arenaceous assemblage below $-1^{\circ} \mathrm{C}$ and a warmer calcareous assemblage around $0^{\circ} \mathrm{C}$. Phleger (1952) found a similar assemblage (dominated by Adercotryma glomeratum and Islandiella norcrossi) in Lancaster Sound, Canadian Arctic, at depths of $200--450 \mathrm{~m}$.

Both the Cassidulina-Cibicides and the Adercotryma-Islandiella assemblages are limited to the area affected by the Polar Spitsbergen Current.

\subsection{Adercotryma - Cribrostromoides assemblage}

This assemblage is found in the deepest part of Storfjordrenna at station 156. The dominant species are Adercotryma glomeratum and Cribrostomoides crassimargo; quite common are Ammotium sp. and Recurvoides turbinatus. The assemblage occurs in extremely cold bottom water $\left(<-1^{\circ} \mathrm{C}\right)$ on finegrained sediment. Solution of shells is indicated by strongly corroded calcareous specimens.

\subsection{Nonion - Cassidulina assemblage}

The assemblage is found in the northern part of Storfjordrenna at the following stations and core depths: $166 / 90-100 \mathrm{~cm}, 139 / 50-70 \mathrm{~cm}$. The dominant species are Cassidulina crassa (23-26\%) and Nonion labradoricum $(17-26 \%)$. Other common species are Islandiella norcrossi $(8-22 \%)$, Elphidium excavatum $(19-15 \%)$, Buccella frigida (4-7\%), and Cassidulina laevigata $(2-5 \%)$. The number of species is $23-30$, the faunal diversity 12 , and the number of specimens per gram sediment up to 130. Planktonic species reach a maximum of $1 \%$.

The composition of the assemblage indicates influence of glaciers. This influence seems to be reduced, however, compared to the Elphidium-Cassidulina assemblage.

\subsection{Elphidium - Cassidulina assemblage}

This assemblage was found only below the bottom surface; it is present in the northern part of Storfjordrenna at the following stations and core depths: $152 / 80-100 \mathrm{~cm}, 154 / 60-85 \mathrm{~cm}, 163 / 85-90 \mathrm{~cm}$, and $166 / 105-115 \mathrm{~cm}$. It occurs in an ice-drop facies of silt and clayey silt containing stones. The assemblage is dominated by Elphidium excavatum and Cassidulina crassa which together compose $65-92 \%$ of the assemblage. Other common species are Cibicides lobatulus $(1-12 \%)$, Cassidulina laevigata $(2-8 \%)$, Nonion barleeanum $(0-5 \%)$ Astrononion gallowayi (1-3\%), and Islandiella norcrossi $(0-3 \%)$.

Elphidium excavatum is mainly represented by the Arctic forma clavata and a few scattered specimens of forma selseyensis. The distribution of this, highly variable species is discussed by Feyling-Hanssen (1972). 
The assemblage is rather poor. The number of species per sample is $11-24$, the faunal diversity $4-11$, and the number of specimens per gram sediment 1.3-51. The content of planktonic specimens varies from 3 to $19 \%$.

The environment of the Elphidium-Cassidulina assemblage is interpreted to have been directly affected by glaciers or by a continuous ice-sheet of supposed Weichselian age.

\section{Stratigraphy and environments}

In the foraminiferal assemblages we have distinguished between two faunal components or groups of species: a glacial or near-glacier component, and an open shelf component. It is obvious that this differentiation is provisional mainly because the distribution of species is only incompletely known. Nevertheless, the present grouping seems useful for environmental interpretation as shown in Fig. 14.

The glacial component includes the following species, although they also occur in other environments: Cassidulina crassa, Elphidium excavatum, Elphidium incertum, Nonion labradoricum, Astrononion gallowayi. The shelf component includes: Cibicides lobatulus, Cassidulina laevigata, Trifarina fluens, Buccella frigida, Buccella tenerrima, Islandiella islandica, Nonion barleeanum.

The investigated cores reveal three successive stages in the Quaternary evolution of the area. The stages are discussed below.

\subsection{Glacial shelf}

A strong glacial influence on the Elphidium-Cassidulina assemblage is expressed by low faunal diversity $(4-11)$. low number of specimens $(1.3-51)$ per gram sediment, and high content of the glacial component (66-93\%). The presence of scattered pebbles in the sediment (silt and clayey silt) indicates rafting by ice in the depositional area. At the same time the area had a slight influx of Atlantic water as indicated by the occurrence of Cassidulina laevigata $(2-8 \%)$ and planktonic species $(3-19 \%)$.

Recent faunas with low diversity, dominance of $C$. crassa and $E$. excavatum, and a smaller content of $\mathcal{N}$. labradoricum and $A$. gallowayi are reported from the following localities near calving glaciers in the fiords of Spitsbergen: outer Isfjorden (Feyling-Hanssen 1964); Van Keulenfjorden, Hornsund, Storfjorden (Nagy 1965); Kongsfjorden (Elverhøi et al. 1980).

The low diversity in Kongsfjorden (op.cit.) seems to be caused mainly by high turbidity and very soft substrate acting as limiting factors. It is probable that these factors are generally of primary importance for the development of typical glaciomarine assemblages of foraminifera. Assemblages of this type are well known from Pleistocene deposits and show quite uniform composition both in shelf and fiord areas, for example: the Kattegat (Fält 1977), the Oslofjord area (Feyling-Hanssen 1964), the Norwegian Channel (Nagy and Ofstad 1980), the continental shelf off Troms and Finnmark (Vorren et al. 1978).

The exact age of the Elphidium-Cassidulina assemblage in the present cores 

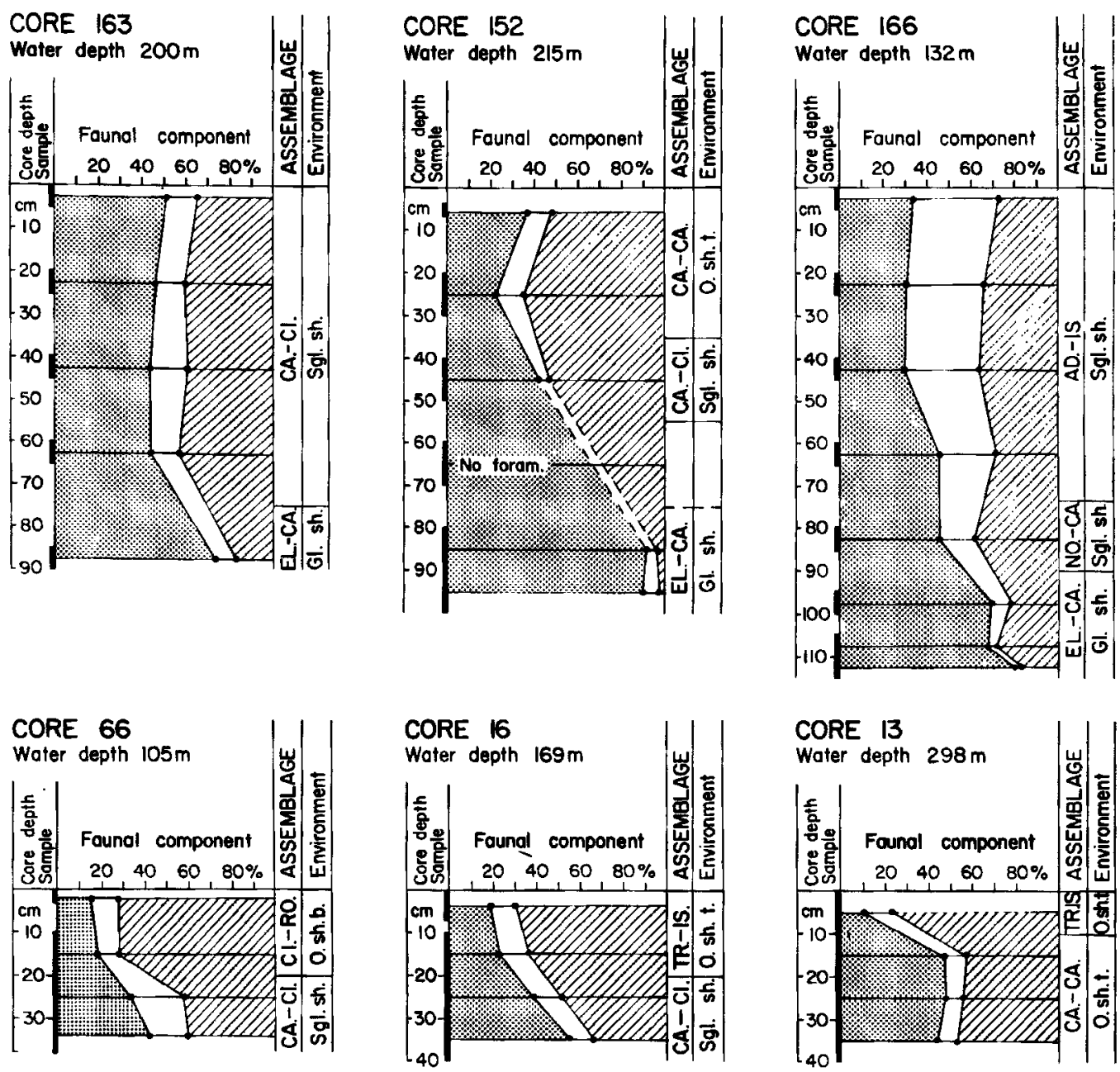

\section{ASSEMBLAGE}

\section{ENVIRONMENT:}
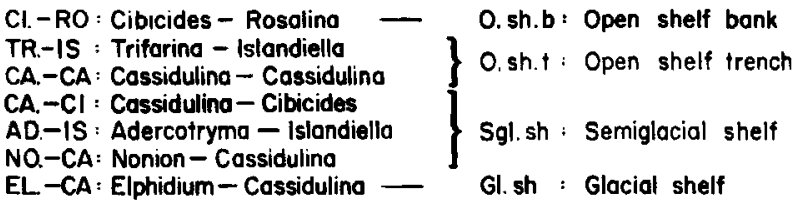

QIIZX Open shelf component

Glaciol component

Sundry

Fig. 14. Distribution of two faunal components in the benthonic assemblages through six cores, to illustrate changes in the depositional environment.

is difficult to decide without radiometric datings. At present it seems most reasonable to assume that the unit was deposited in Middle to Late Weichselian. The occurrence of an extensive Weichselian ice-sheet covering the northern and western parts of the Barents Sea was proposed by Hoppe (1970). He suggested that the central and thickest part of the ice-cap in the last part of the glaciation was located to the area northeast of Hopen. Recent discussion of the subject is given by Grosswald (1980) and Elverhøi and Bomstad (1980). 
A major glacial period in the Barents Sea is indicated by moraine ridges on the southern slope of Spitsbergenbanken, in front of and inside the submarine trough Leirdypet (Elverhøi and Kristoffersen 1978). These features are probably related to the Middle Weichselian ice maximum (18-20 000 years B.P.).

As shown by Fig. 15, the Elphidium-Cassidulina assemblage in the analyzed cores was only found in Storfjordrenna. Its presence must, however, be anticipated over much of the Barents Shelf below younger assemblages.

\subsection{Semiglacial shelf}

In Storfjordrenna the glacial Elphidium-Cassidulina assemblage is overlain by the Cassidulina-Cibicides assemblage at stations 163, 152, and 154 . The Cassidulina-Cibicides assemblage is also present on Spitsbergenbanken (station 66) and in Bjørnøyrenna (stations 4 and 16) where it is overlain by younger assemblages forming the sea floor. As shown in Fig. 14 the Cassidulina-Cibicides assemblage contains intermediate amounts of glacial species. The same is true for the Nonion-Cassidulina and Adercotryma-Islandiella assemblages occurring in Storfjordrenna (cores 166 and 139).

These three assemblages are regarded as transitional between a glaciated and an open shelf. It seems probable that these semiglacial units are of very late Weichselian - early Holocene age in Bjørnøyrenna and on Spitsbergenbanken, where they were formed in association with the final phase of the retreat of the ice to its present distribution areas. In Storfjordrenna their deposition probably started in latest Weichselian - early Holocene and continues today in the northernmost part of the trench.

\subsection{Open shelf}

In four assemblages occurring from the present sea floor down to varying sediment depths, the amount of glacial species is strongly reduced. These assemblages are: the Cibicides-Rosalina on Spitsbergenbanken, the TrifarinaIslandiella in Bjørnøyrenna, the Cassidulina-Cassidulina and AdercotrymaCribrostomoides in Storfjordrenna. They were formed on the deglaciated or open shelf during the Holocene, under conditions essentially similar to those of the present day. It is, however, clear that minor changes have taken place during the Holocene, particularly in Storfjordrenna.

Carbon-14 datings were carried out for Bjørlykke et al. (1978) on eight samples of bivalve shells and Balanus plates taken from sediments containing the Cibicides-Rosalina assemblage on Spitsbergenbanken. The ages obtained are in the interval $280-4370$ years B.P. for seven samples, and 8730 years B.P. for the remaining one. In western Storfjordrenna one Carbon-14 dating was made on bivalve shells from $18 \mathrm{~cm}$ sediment depth (Elverhøi and Bomstad 1980) apparently from sediments equivalent to the Cassidulina-Cassidulina assemblages. The age obtained here is 7300 years B.P. showing that the environment has existed at least in the Middle and Late Holocene. 


\subsection{Stratigraphical changes in Storfjordrenna}

On the southern slope and in the centre of Storfjordrenna eight cores contain the Cassidulina-Cassidulina assemblage throughout their length. Marked vertical changes within the fauna occur in the northern part of the trench, where obvious differences are also found between the eastern and western areas (Fig. 15).

In the west (cores 163,152,154,155), the cold water Cassidulina-Cibicides assemblage is replaced southwards by the warmer Cassidulina-Cassidulina assemblage. This relationship indicates that the Polar Spitsbergen Current earlier in the Holocene had a more southerly path than it has today. Later the current retreated northwards and was replaced by Atlantic water producing the Cassidulina-Cassidulina assemblage.

In the eastern part of the trench the stratigraphy is more varied. The warm Cassidulina-Cassidulina assemblage at station 139 occurs below the colder Adercotryma-Islandiella and Nonion-Cassidulina assemblages. This position of the Cassidulina-Cassidulina assemblage suggests that the Atlantic water in northeastern Storfjordrenna had a Holocene retreat southwards. The retreat was followed by a readvance towards the north as shown by the recent distribution of the Cassidulina-Cassidulina assemblage.

\section{Postmortem changes in surface assemblages}

\subsection{Dissolution of calcareous shells}

The degree of dissolution of calcareous foraminifera is strongly variable within the study area, and is illustrated in three profiles in Fig. 16.

Lowest values of dissolution are found on Spitsbergenbanken where $0-10 \%$ of the shells are etched. An exception is station 99 with a considerably higher amount of etched shells. The generally low values of dissolution on the bank must be related to high degree of carbonate saturation in this high energy area. In this connection it may be noted that the bottom sediments contain $25-90 \%$ carbonate.

In Bjørnøyrenna and Storf jordrenna the degree of dissolution is considerably higher, with frequencies of etched specimens $10-85 \%$. The proportion of etched specimens shows an increase with increasing depth along the profile from station 57 to 155 in Fig. 16; in the two other profiles the increase is quite irregular. Highest values of dissolution are found at station 156 at a depth of $332 \mathrm{~m}$ in Storfjordrenna. On the bottom surface at this station the fauna consists of $25 \%$ calcareous species and the rest is arenaceous. All calcareous specimens were etched to varying degrees.

The high degree of dissolution in Storfjordrenna is probably caused by a combination of several factors: 1) Low temperatures $\left(<-1^{\circ} \mathrm{C}\right)$ are measured in the axial part of the trench. 2) Aphotic conditions below winter ice on the shelf may increase the $\mathrm{CO}_{2}$ content of the outflowing bottom water. 3) The sedimentation rates in the Barents Sea are generally low (Bjørlykke et al. 1978), implying a greater amount of time available for dissolution before burial. 


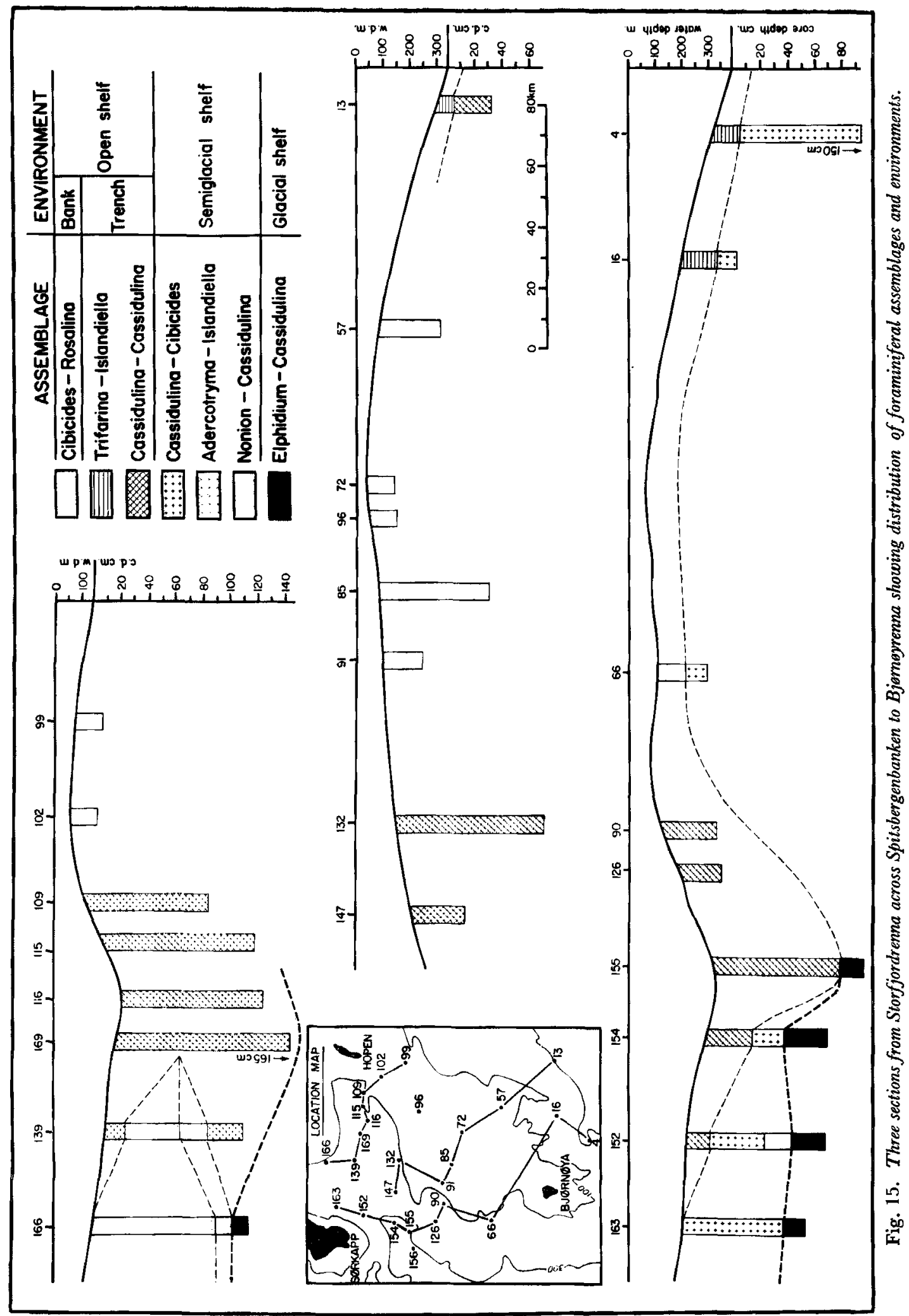




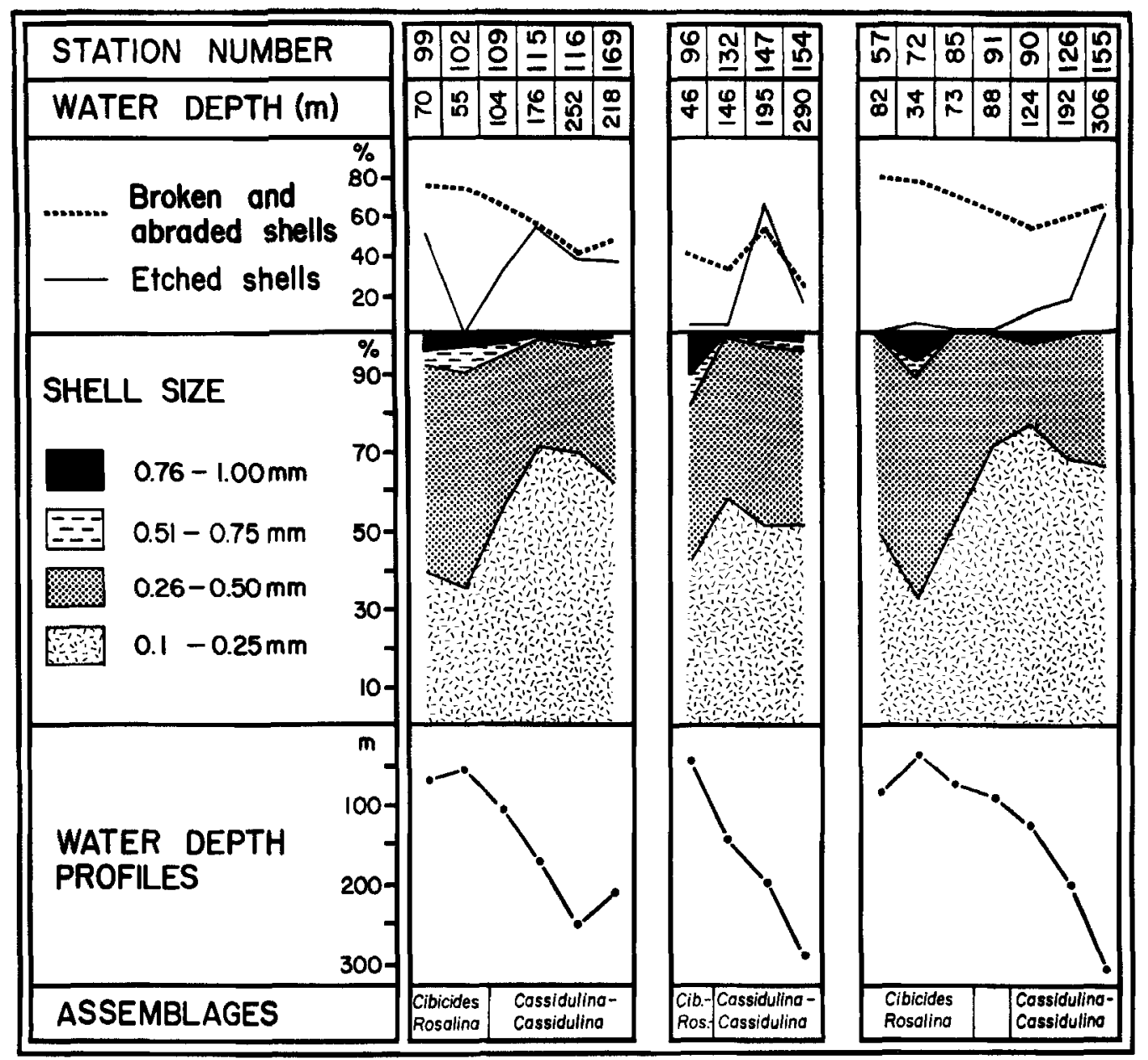

Fig. 16. Distribution of etched, abraded, and different size-grades of foraminiferal shells along three profiles from Storfjordrenna to Spitsbergenbanken.

\subsection{Abrasion and breakage}

In the surface samples the amount of mechanically damaged shells is greatest on Spitsbergenbanken where up to $80 \%$ are broken. The proportion of broken shells decreases generally with increasing depth, and reaches $40 \%$ at $310 \mathrm{~m}$ in Bjørnøyrenna and $26 \%$ at $290 \mathrm{~m}$ in Storf jordrenna.

In the deepest parts of the profiles shown in Fig. 16 there is a correlation between the amount of broken and etched shells. This feature is explained by the fact that etched shells break more easily both during transport and within the sediment. On the other hand, abraded surfaces will increase the effect of solution (Murray and Wright 1970). It must be mentioned, however, that the samples containing most broken shells $(71-80 \%)$ are from Spitsbergenbanken where the frequency of etched specimens is generally low $(0-10 \%)$, and the broken shells show perfect surface. 
Shells with traces of biological destruction are found on Spitsbergenbanken, but they are rare. Borings made by predators and algae are observed on a few specimens. We can, therefore, conclude that the large amount of broken shells on the bank are mainly the result of physical strain caused by current activity.

\subsection{Transport and redeposition}

The surface sediments of Spitsbergenbanken are composed mainly of biogenic carbonate sand and gravel consisting chiefly of fragments of molluscs, echinoderms, bryozoans and cirripeds. Size measurements of foraminifera show that the assemblage on the bank contains fewer shells in the interval 0.10$0.25 \mathrm{~mm}$ compared with the assemblage in Storfjordrenna. In the shallowest areas of the bank this fraction constitutes $32 \%$ of the assemblage, whereas in Storfjordrenna it composes $50-70 \%$. In contrast, the fraction $0.5-1.0 \mathrm{~mm}$ has its maximum on the bank with $20 \%$, while in Storfjordrenna it accounts for $5 \%$ or less.

Fig. 16 shows that on Spitsbergenbanken there is a certain correlation between increased amounts of broken shells and low content of the smallest size fraction of foraminifera. The enrichment of the larger fractions on the bank has two possible reasons: 1) By abrasion the smallest and most thin-walled foraminifera may be completely destroyed while the larger, and more resistant forms will suffer only lighter damage. 2) The smallest foraminifera are transported out of the bank area by currents. These smaller shells are believed to be redeposited in deeper and quieter water on the flanks of the bank. Such redeposition is indicated by the enrichment of the smallest shell fraction $0.10-$ $0.25 \mathrm{~mm}$ ) on the northern flank of the bank in the depth interval $100-250 \mathrm{~m}$.

\section{Summary and conclusions}

The investigated area, Spitsbergenbanken with its flanking trenches Bjørnøyrenna and Storfjordrenna, is affected by a complicated pattern of cold and warm currents. The topographical tripartition of the area is reflected in a general way by the distribution of sediments and foraminifera. Foraminiferal analyses of 2 cores and four grab and dredge samples have resulted in the following main conclusions:

1. The Fisher $a$ indices and the relative frequency of the suborders Textulariina, Miliolina, and Rotaliina correspond to the pattern of shelf seas of lower latitudes.

2. The number of foraminiferal shells per gram sediment has higher values on Spitsbergenbanken than in the trenches. The values on the bank are explained by high organic production and strongly restricted supply of terrigene clastics. 
3. The proportion of areanaceous foraminifera is relatively high in the outer, central, and northern parts of Storfjordrenna. This is probably due to low temperatures combined with fine-grained substrate. Extensive dissolution of calcareous shells occurred in the outer part of the trench at great depth.

4. The distribution pattern of planktonic foraminifera and Cassidulina laevigata is related to inflowing Atlantic water masses. Both have highest values in Storfjordrenna.

5. The frequency of Nonion baleeanum increases from the bank to the trenches with increasing depth, as is the case in the North Sea.

6. The foraminiferal assemblage in the high energy environment of Spitsbergenbanken is dominated by sessile species, and contains higher proportions of plastogamic forms and miliolids than the assemblages occurring in the trenches.

7. In the Quaternary evolution of the area three successive stages are recognized: glacial shelf sediments of probable Middle and Late Weichselian age containing a foraminiferal assemblage similar to those of Recent glacier dominated environments; semiglacial shelf, or transitional environment of the Late Weichselian and Holocene; open, or deglaciated shelf of the Holocene.

8. Minor Holocene faunal changes in the northern part of Storfjordrenna are related to advance and retreat of the northern limit of inflowing Atlantic water.

9. Distinction between a glacial and a shelf faunal component is useful for environmental interpretation.

10. The degree of dissolution of calcareous shells is strongly variable but shows lowest values on Spitsbergenbanken where a high degree of carbonate saturation is assumed. Abrasion and breakage of shells are most common on the bank and decrease generally with increasing depth in the trenches.

11. Size measurements of foraminifera indicate that small forms are winnowed from the high energy areas of the bank and redeposited in areas of lower energy in the trenches.

\section{Faunal reference list and distribution chart}

Of the 218 species recognized in the present material, 57 are entered in the following reference list. Listed are all species mentioned in the text or on the illustrations. The species name used here is followed by reference to one newer publication and the original publication.

The distribution chart in Fig. 17 contains the surface samples from all stations. It shows the percentage frequency of all species which occur with a frequency of $1 \%$ or more in at least one surface sample. Illustrations of 38 species are given in plates 1 to 4 . 


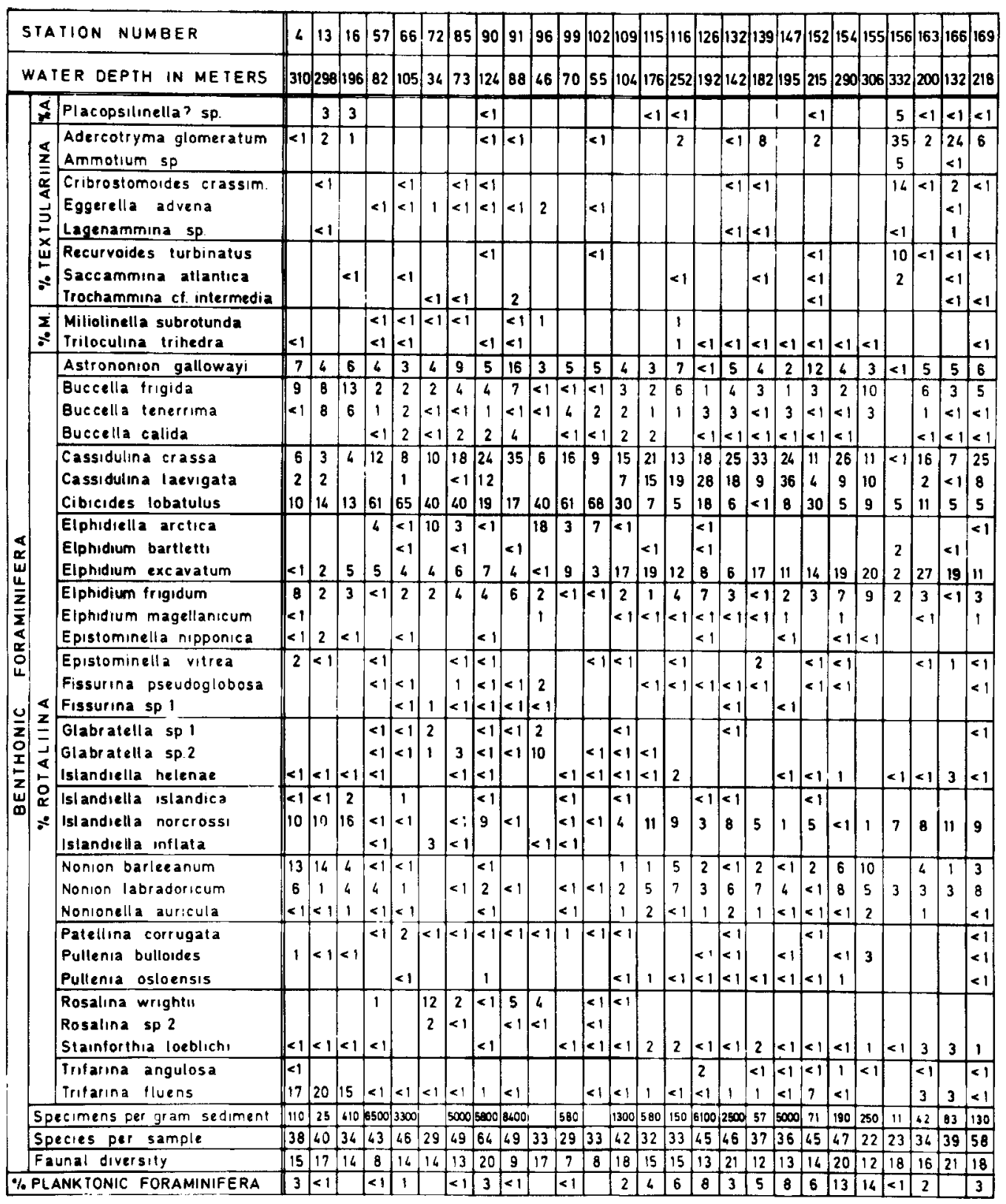

Fig. 17. Distribution chart of foraminifera in surface sediments. 
Placopsilinella sp.

\section{ALLOGROMIINA}

\section{TEXTULARIINA}

Adercotryma glomeratum (Brady): Loeblich and Tappan 1953, Lituola glomerata Brady 1878.

Ammotium sp.

Cribrostomoides crassimargo (Norman): Alveolophragmium crassimargo (Norman) Loeblich and Tappan 1953; Haplophragmium crassimargo Norman 1892.

Eggerella advena (Cushamn): Loeblich and Tappan 1953; Verneuilina advena Cushman 1922.

Lagenammina sp.

Recurvoides turbinatus (Brady): Loeblich and Tappan 1953; Haplophragmium turbinatum Brady 1881.

Saccammina atlantica (Cushman): Sen Gupta 1971; Proteonia atlantica Cushman 1944.

Spiroplectammina biformis (Parker and Jones): Loeblich and Tappan 1953; Textularia agglutinans d'Orbigny, var. biformis Parker and Jones 1865.

Trochammina cf. intermedia Rhumbler: Høglund 1947; Trochammina squamata intermedia Rhumbler 1938.

\section{MILIOLINA}

Cyclogyra involvens (Reuss): Cornuspira involvens Loeblich and Tappan 1953; Operculina involvens Reuss 1850.

Miliolinella subrotunda: Feyling-Hanssen 1976; Vermiculum subrotundum Montague 1803.

Triloculina trihedra Loeblich and Tappan 1953.

\section{ROTALIINA, BENTHONIC}

Astronoion gallowayi Loeblich and Tappan 1953.

Buccella frigida (Cushman): Feyling-Hanssen et al. 1971; Pulvinulina frigida Cushman 1922.

Buccella tenerrima (Bandy): Feyling-Hanssen et al. 1971; Rotalina tenerrima Bandy 1950.

Bucella calida (Cushman and Cole): Buccella frigida var. calida FeylingHanssen 1976; Eponides frigida (Cushman) var. calida Cushman and Cole 1930.

Cassidulina crassa d'Orbigny: Feyling-Hanssen et al. 1971; d'Orbigny 1839.

Cassidulina laevigala d'Orbigny: Feyling-Hanssen et al. 1971; d'Orbigny 1826.

Cibicides lobatulus (Walker and Jacob): Feyling-Hanssen 1964; Nautilus lobatilus Walker and Jacob 1798. 
Elphidiella arctica (Parker and Jones): Loeblich and Tappan 1953; Polystomella arctica Parker and Jones in Brady 1864.

Elphidium bartletti Cushman 1933.

Elphidium excavatum (Terquem) forma clavata Cushman: Feyling-Hanssen 1972;Elphidium incertum var. clavatum Cushman 1930.

Elphidium frigidum Cushman 1933.

Elphidium incertum (Williamson): Buzas 1966; Polystromella umbilicatula var. incerta Williamson 1858.

Elphidium magellanicum Heron-Allen and Earland: Feyling-Hanssen et al. 1971; Heron-Allen and Farland 1932.

Epistominella nipponica Kuwano: Kihle and Lofaldli 1973; Kuwano 1962.

Epistominella vitrea Parker: Todd and Low 1967; Parker et al. 1953.

Fissurina pseudoglobosa (Buchner): Lagena pseudoglobosa Buchner 1940.

Fissurina semimarginata (Reuss): Loeblich and Tappan 1953; Lagena marginata Williamson var. semimarginata Reuss 1870.

Fissurina sp. 1

Glabratella sp. 1

Glabratella sp. 2

Islandiella helenae Feyling-Hanssen and Buzas 1976.

Islandiella inflata (Gudina): Feyling-Hanssen 1976; Cassidulina inflata Gudina 1966.

Islandiella islandica (Nørvang): Feyling-Hanssen et al. 1971; Cassidulina islandica Nørvang 1945.

Islandiella norcrossi (Cushman): Feyling-Hanssen et al. 1971; Cassidulina norcrossi Cushman 1933.

Lamarckina haliotidea (Heron-Allen and Earland): Cushman 1931; Pulvinulina haliotidea Heron-Allen and Earland 1911.

Nonion barleeanum (Williamson): Feyling-Hanssen et al. 1971; Nonionina barleeanum Williamson 1858.

Nonion labradoricum (Dawson): Loeblich and Tappan 1953; Nonionina labradorica Dawson 1860.

Nonionella auricula Heron-Allen and Earland: Loeblich and Tappan 19.53; Heron-Allen and Earland 1930.

Patellina corrugata Williamson: Loeblich and Tappan 1953; Williamson 1858. Pullenia bulloides (d'Orbigny): Feyling-Hanssen et al. 1971; Nonionina bulloides d'Orbigny 1826.

Pullenia osloensis Feyling-Hanssen 1954.

Rosalina vilardeboana d'Orbigny: Barker 1960; d'Orbigny 1839.

Rosalina williamsoni (Chapman and Parr): Haynes 1973; Discorbis williamsoni Chapman and Parr 1932.

Rosalina wrightii (Brady): Cooper 1964; Discorbis wrightii Brady 1881.

Rosalina sp. 1

Rosalina sp. 2

Spirillina vivipara Ehrenberg: Loeblich and Tappan 1953; Ehrenberg 1843. 
Stainforthia loeblichi (Feyling-Hanssen): Kihle and Løfaldi 1973; Virgulina loeblichi Feyling-Hanssen 1954.

Trifarina angulosa (Williamson): Feyling-Hanssen et al. 1971; Uvigerina angulosa Williamson 1858.

Trifarina fluens (Todd): Angulogerina fluens Todd in Cushman and Todd 1947.

\section{ROTALIINA, PLANKTONIC}

Globigerina bulloides d'Orbigny: Bé 1977; d'Orbigny 1826.

Globigerina quinqueloba Natland: Bé 1977; Natland 1938.

Globigerinita glutinata (Egger): Bé 1977; Globigerina glutinata Egger 1893.

Globoquadrina dutertrei d'Orbigny: Bé 1977; Globigerina dutertrei d'Orbigny 1839.

Globoquadrina pachyderma (Ehrenberg): Bé 1977; Aristerospira pachyderma Ehrenberg 1861.

\section{Acknowledgements}

We want to express our most sincere thanks to the following persons for discussions, useful suggestions and critical reading of the manuscript: Anders Elverhøi, Norwegian Polar Research Institute, Oslo; Rolf W. Feyling-Hanssen, Micropaleontological departement, University of Aarhus; Adrian Read and Jörn Thiede, Institute of Geology, University of Oslo; and Tore O. Vorren, Institute of Biology and Geology, University of Tromsø.

\section{References}

Bjørlykke, K., B. Bue, and A. Elverhøi, 1978: Quaternary sediments in the northwestern part of the Barents Sea and their relation to the underlying Mesozoic bed rock. Sedimento$\log y$ 25: 227-246.

Boulton, G.S., 1979: Glacial history of the Spitsbergen archipelago and the problem of a Barents Shelf ice sheet. Boreas 8 (1): $31-57$.

Burmistrova, I.I., 1967: Modern distribution of Foraminifera and stratigraphy of the Late Quaternary sediments in the Barents Sea. Okeanologiya 2: 302-208. (Text in Russian, English summary).

Cushman, J.A., 1948: Arctic Foraminifera. Cushman Lab. Foram. Res., spec. Publ. 23. 80 pp.

Elverhøi, A. and K. Bomstad, 1980: Late Weichselian glacial and marine sedimentation in the western, central Barents Sea. Norsk Polarinst. Rapport Nr. 3. 29 pp.

Elverhøi, A. and Y. Kristoffersen, 1978: Glacial deposits southeast of Bjørnøya, northwestern part of the Barents Sea. Norsk Polarinst. Arbok 1977: 209-215.

Elverhøi, A., O. Liestøl, and J. Nagy, 1980: Glacial erosion, sedimentation and microfauna in the inner part of Kongsfjorden, Spitsbergen. Norsk Polarinst. Skrifter. Nr. 172: $33-61$.

Feyling-Hanssen, R.W., 1964: Foraminifera in Late Quaternary deposits from the Oslofjord area. Norges geol. Unders. $225.383 \mathrm{pp}$

- 1972: The foraminifer Elphidium cxcavatum (Terquen) and its variant forms. Micropal. 18 (3): $337-354$.

- 1976: A Mid-Wisconsinian Interstadial on Broughton Island, Arctic Canada, and its Foraminifera. Arctic and Alphine Res. 8 (2): 161-182. 
Fält, L.-M., 1977: Gränsen Pleistocen/Holocen i marina sediment utanför Svenska Västkusten. Chalmers Tekniska Högskola. Göteborg Universilel, Geologiska Institutionen, publ. A 14. $39 \mathrm{pp}$.

Goës, A., 1894: A synopsis of the Arctic and Scandinavian Rccent Foraminifera hitherto discovered. Kgl. Svenska Vet.-Akad. Handl. 25 (9).

Grosswald, M.G., 1980: Late Weichselian ice sheet of northern Eurasia. Quaternary Research 13: 1-32.

Hoppe, G., 1970: The Würm Ice Sheets of Northern and Arctic Europe. Acta Geographica Lodzimsea 24: 205-215.

Jarke, J., 1960: Beitrag zur Kenntnis der Foraminiferenfauna der mittleren und westlichen Barents-See. Internationale' Revue der gesamten Hydrobiologie 45 (4): 581-564.

- 1961: Die Beziehungen zwischen hydrographischen Verhältnissen, Faziesentwicklung und Foraminiferenverbreitung in der Nordsee als Vorbild für die Verhältnisse während der Miocän-Zeit. Meyniana 10: 21-36.

Kiær, H., 1899: Thalamophora. Den Norske Nordhavs-expedisjon, 1876-78. 7 (Zoology) (4): $1-13$.

Lange, W., 1956: Grundproben aus Skagerrak und Kattegat, mikro-faunistisch und sedimentpetrographisch untersucht. Meyniana 5: 51-86.

Loeblich, A.R. and H. Tappan, 1953: Studies of Arctic Foraminifera. Smithsonian Misc. Coll. 121 (7). $150 \mathrm{pp}$.

Matisov, G.C., 1977: Bottom gemorphology and the problem of Pleistocene glaciation of the Barents Sea shelf (in Russian). Gemorfologija 2. Maskva.

Murray, J. W., 1973: Distribution and Ecology of Living Benthic Foraminiferids. London. Heinemann Education Books, 274 pp.

Murray, J.W. and C.A. Wright, 1970: Surface textures of calcareous foraminiferids. Palaeontology 13: 184-187.

Nagy, J., 1965: Foraminifera in some bottom samples from shallow waters in Vestspitsbergen. Norsk Polarinst. Arbok 1963: 109-125.

Nagy, J. and K. Ofstad, 1980: Quaternary foraminifera and sediments in the Norwegian Channel. Boreas 9 (1): 39-52.

Norvang, A., 1945: The zoology of Iceland. Foraminilera 2 (2): 1-79. Copenhagen and Reykjavik: E. Munksgaard.

Phleger, R.B., 1952: Foraminifera distribution in some sediment samples from the Canadian and Greenland Arctic. Conlr. Cushman Found. Foram. Res. 3 (2): 80-89.

Risdal, D., 1964: Foraminiferfaunaenes relasjon til dybdeforholdene $i$ Oslof jorden, med en diskusjon av de senkvartare foraminifersoner. Norges geol. Unders. $226.142 \mathrm{pp}$.

Sanders, H.L., 1960: Benthic studies in Buzzards Bay. III. The structure of the soft-bottom community. Limnol. Oceanogr. 5: 138-153.

Sen Gupta, B.K., 1972: Distribution of Holocene bcnthonic Foraminifera on the Atlantic continental shelf of North America. Internat. Geol. Congr., 24th. Montreal, 1972, Sec. 8: $125-134$.

Vorren, T.O., J.F. Strass, and O.W. Lind-Hansen, 1978: Late Quaternary Sediments and Stratigraphy on the Continental Shelf off Troms and West Finnmark, Northern Norway. Quaternary Research 10: 340-365.

Walton, W.R., 1964: Recent foraminiferal ecology and paleoecology. Pp. 151-237 in: J. Imbrie, and N.D. Newell, (editors) Approaches to Paleoecology Wiley and Sons, New York. 


\section{Plates 1-4}

All figured specimens are deposited in the collection of the Paleontological Museum, University of Oslo, and may be obtained by their assigned numbers (in brackets). The sample numbers refer to bulk sample number or core number and depth in $\mathrm{cm}$. The scanning electron micrographs were taken at the Electron microscope laboratory for biology, University of Oslo.

\section{PLATE 1}

ALLOGROMIINA, TEXTULARIINA, MILIOLINA, ROTALIINA

Fig. 1. Placopsilinella? sp. Detail of the surface of a specimen from Trifarina-Islandiella assemblage, sample 16/0-7 (A37941); SEM $\times 1500$.

Fig. 2. Placopsilinella ? sp. Edge view of a specimen from Trifarina-Islandiella assemblage, sample 16/0-7 (A37942); $\times 100$.

Fig. 3. Lagenammina sp. from Cassidulina-Cassidulina assemblage, sample $132 / 0 \multimap 10$ (A37943); $\times 75$.

Fig. 4. Reophax curtus from Adercotryma-Islandiella assemblage, sample $166 / 0-5$ (A37944); $\times 75$.

Fig. 5. Cribrostomoides crassimargo from Adercotryma-Cribrostomoides assemblage, sample 156/0-5 (A37945); $\times 50$.

Fig. 6. Ammotium sp., a. side view and b. edge view of a specimen from AdercotrymaIslandiella assemblage, sample 166/20-25 (A37946); $\times 75$.

Fig. 7. Adercotryma glomeratum from Adercotryma-Cribrostomoides assemblage, sample 156/0-5 (A37947); $\times 75$.

Fig. 8. Trochammina cf. intermedia. a. Spiral view and b. umbilical view of a specimen from Cassidulina-Cassidulina assemblage sample 152/4-10 (A37948); $\times 100$.

Fig. 9. Recurvoides lurbinatus. a. Spiral view and b. umbilical view of a specimen from Adercotryma-Cribrostomoides assemblage, sample 156/60-65 (A37949); $\times 75$.

Fig. 10. Miliolinella subrotunda from Cibicides-Rosalina assemblage, sample 85/40-45 (A37950); $\times 75$.

Fig. 11. Cyclogyra involvens from Cibicides-Rosalina assemblage, sample 85/40-45 (A37951); $\times 100$.

Fig. 12. Fissurina sp. 1. a. Side view and b. edge view of a specimen from Cibicides-Rosalina assemblage, sample 91/0-5 (A37952); $\times 100$.

Fig. 13. Spirillina vivipara from Cibicides-Rosalina assemblage, sample 76 (A37953); $\times 100$.

Fig. 14. Patellina corrugata from Cibicides-Rosalina assemblage, sample 66/10-20 (A37954); $\times 100$.

Fig. 15. Lamarckina haliotidea. Umbilical view of a specimen from Cibicides-Rosalina assemblage, sample 85/0-5 (A37955); SEM $\times 150$.

Fig. 16. Islandiella islandica from Cibicides-Rosalina assemblage, sample 66/0-3 (A37956); $\times 75$.

Fig. 17. Islandiella helenae from Cassidulina-Cassidulina assemblage, sample 109/0-10 (A37957); $\times 75$.

Fig. 18. Islandiella norcrossi from Cassidulina-Cassidulina assemblage, sample 109/40-50 (A37958); $\times 75$.

Fig. 19. Islandiella inflata. Opposite sides of a specimen from Cibicides-Rosalina assemblage, sample 85/0-5 (A37959); $\times 75$.

Fig. 20. Stainforthia loeblichi from Trifarina-Islandiella assemblage, sample $4 / 10-15$ (A37960); $\times 75$.

Fig. 21. Trifarina fluens from Trifarina-Islandiella assemblage, sample 16/0-7 (A37961); $\mathrm{SEM} \times 100$.

Fig. 22. Trifarina angulosa from Cassidulina-Cassidulina assemblage, samlpe 126/0--3 $\mathrm{SEM} \times 100$. 
PLATE 1

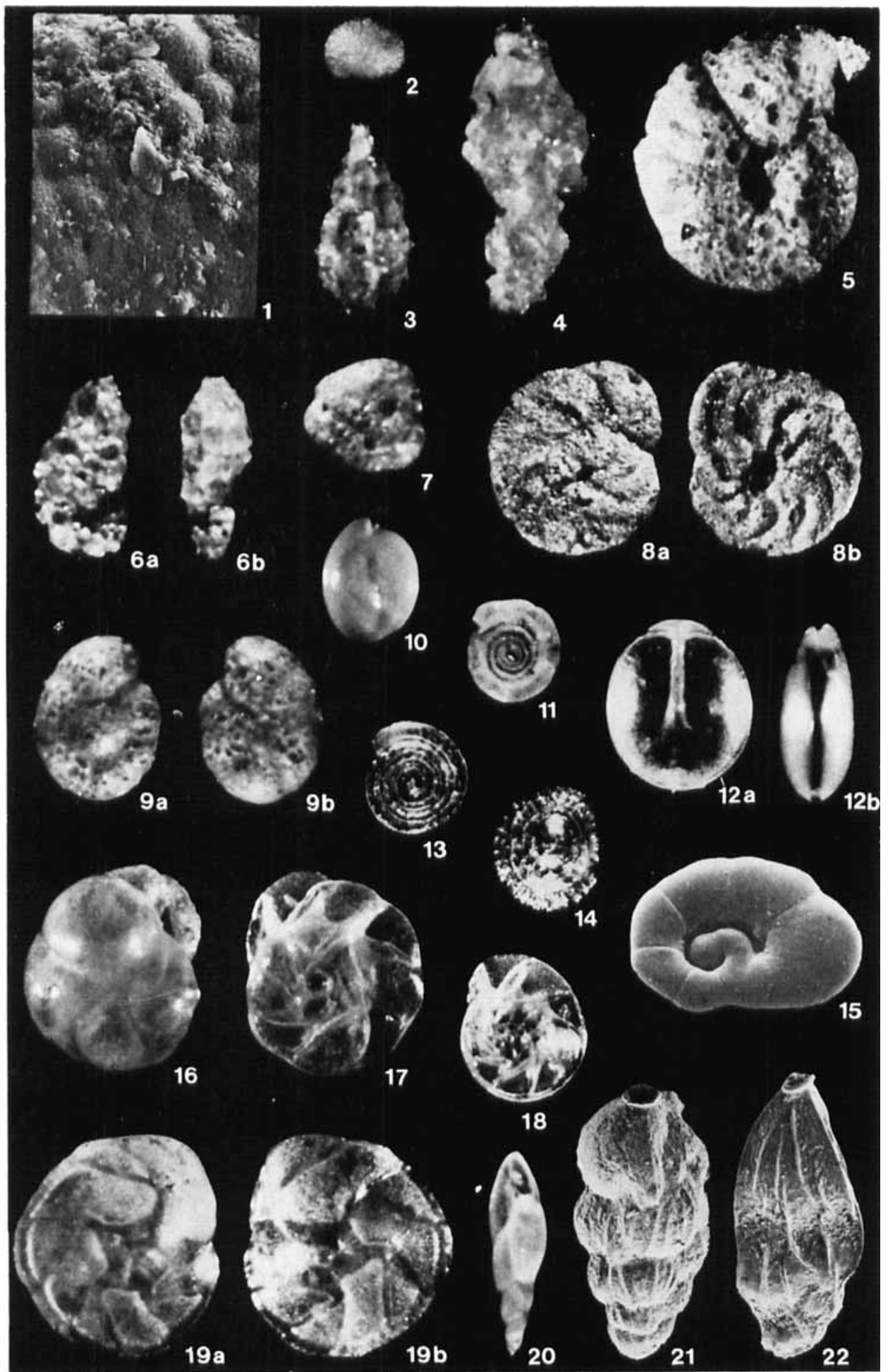




\section{PLATE 2}

\section{ROTALIINA}

a. Spiral view, b. edge view and c. umbilical view.

Fig. 1. Buciella tenerrima from Cibicides-Rosalina assemblage, sample 66/0-3 (A37963); $\times 75$.

Fig. 2. Buccella frigida from Cibicides-Rosalina assemblage, sample 66/10-20 (A37964); $\times 100$.

Fig. 3. Buccella calida from Cibicides-Rosalina assemblage, sample 91/0-5 (A37965); $\times 100$.

Fig. 4. Rosalina vilardeboana from Cassidulina-Cassidulina assemblage, sample 109/0-10 (A37966); $\times 75$.

Fig. 5. Buccella calida from Cibicides-Rosalina assemblage, sample 91/0 -5 (A37967); $\mathrm{SEM} \times 150$.

Fig. 6. Buccella frigida from Cassidulina-Cassidulina assemblage, sample 115/100-110 (A37968); SEM $\times 150$.

Fig. 7. Rosalina cf. wrightii. Megalospheric specimen from Cibicides-Rosalina assemblage, sample 57/0-10 (A37969); × 75 .

Fig. 8. Rosalina williamsoni from Cibicides-Rosalina assemblage, sample 91/0-5 (A37970); $\times 100$.

Fig. 9. Rosalina sp.3 from Cibicides-Rosalina assemblage, sample 85/0-5 (A37971); $\times 100$.

Fig. 10. Rosalina sp.1 from Cibicides-Rosalina assemblage, sample 90/30-40 (A37972); $\times 100$.

Fig. 11. Rosalina wrightii. Microspheric specimen from Cibicides-Rosalina assemblage, sample 91/25-30 (A37973); × 75 .

Fig. 12. Glabratella sp.1 from Cibicides-Rosalina assemblage, sample 85/40-45 (A37974); $\times 100$.

Fig. 13. Glabratella sp.2 from Cibicides-Rosalina assemblage, sample 85/75--80 (A37975); $\times 100$. 
PLATE 2

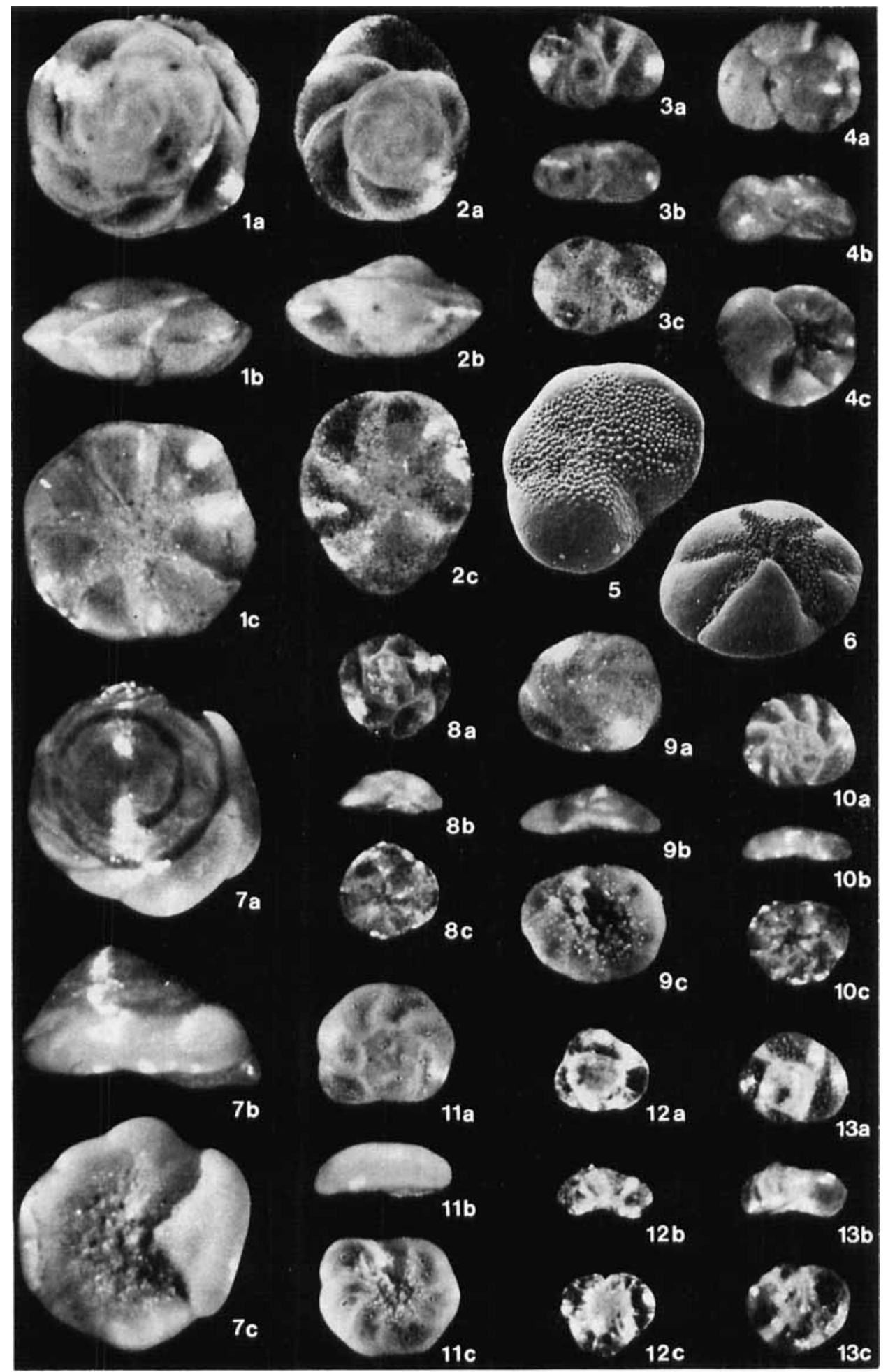




\section{PLATE 3}

\section{ROTALIINA}

Fig. 1. Rosalina wrightii. Umbilical view of a microspheric specimen from Gibicides-Rosalina assemblage, sample 72 (A37976); SEM $\times 100$.

Fig. 2. Rosalina vilardeboana. Umbilical view of a specimen from Cassidulina-Cassidulina assemblage, sample 109/0-10 (A37977); SEM $\times 100$.

Fig. 3. Rosalina sp. 1. Umbilical view of a specimen from Cibicides-Rosalina assemblage, sample 90/30-40 (A37978); SEM $\times 150$.

Fig. 4. Rosalina williamsoni. Umbilical view of a specimen from Cibicides-Rosalina assemblage, sample 91/0-5 (A37979); SEM × 150 .

Fig. 5. Glabratella sp. 2. Umbilical view showing tegilla of a specimen from CibicidesRosalina assemblage, sample 85/40-45 (A37980); SEM $\times 150$.

Fig. 6. Glabratella sp. 1. Umbilical view of a specimen from Cibicides-Rosalina assemblage, sample 91/25-30 (A37981); SEM $\times 250$.

Fig. 7. Rosalina sp. 2. Umbilical view of a specimen from Cibicides-Rosalina assemblage, sample 72 (A37982); SEM $\times 150$.

Fig. 8. Rosalina wrightii. Umbilical view of a microspheric specimen from Cibicides-Rosalina assemblage, sample 72 (A37983); SEM $\times 150$.

Fig. 9. Elphidium excavatum from Cibicides-Rosalina assemblage, sample 66/10-20 (A37984); $\times 100$.

Fig. 10. Elphidium excavalum from western Barents Sea (A37985); $\times 75$.

Fig. 11. Cibicides lobatulus. a. Spiral view and b. umbilical vicw of a specimen from GibicidesRosalina assemblage, sample 66/0-3 (A37986); $\times 50$.

Fig. 12. Elphidum frigidum from Cassidulina-Cassidulina assemblage, sample 154/0-5 (A37987); $\times 75$.

Fig. 13. Cassidulina crassa from Elphidium-Cassidulina assemblage, sample 166/110-115 (A37988); $\times 75$.

Fig. 14. Elphidiella arctica from Cassidulina-Cibicides assemblage, sample 66/20-30 (A37989); $\times 50$.

Fig. 15. Nonion barleeanum. a. Side view and $b$. apertural view of a specimen from TrifarinaIslandiella assemblage, sample 4/0-5 (A37990); $\times 75$.

Fig. 16. Astrononion gallowayi from Cibicides-Rosalina assemblage, sample 66/10-20 (A37991); $\times 75$.

Fig. 17. Nonion labradoricum. a. Side view and b. apertural view of a specimen from CassidulinaCassidulina assemblage, sample 115/100-110 (A37992); $\times 75$.

Fig. 18. Cassidulina laevigata from Cassidulina-Cassidulina assemblage, sample 109/100 -110 (A37993); $\times 75$. 
PLATE 3

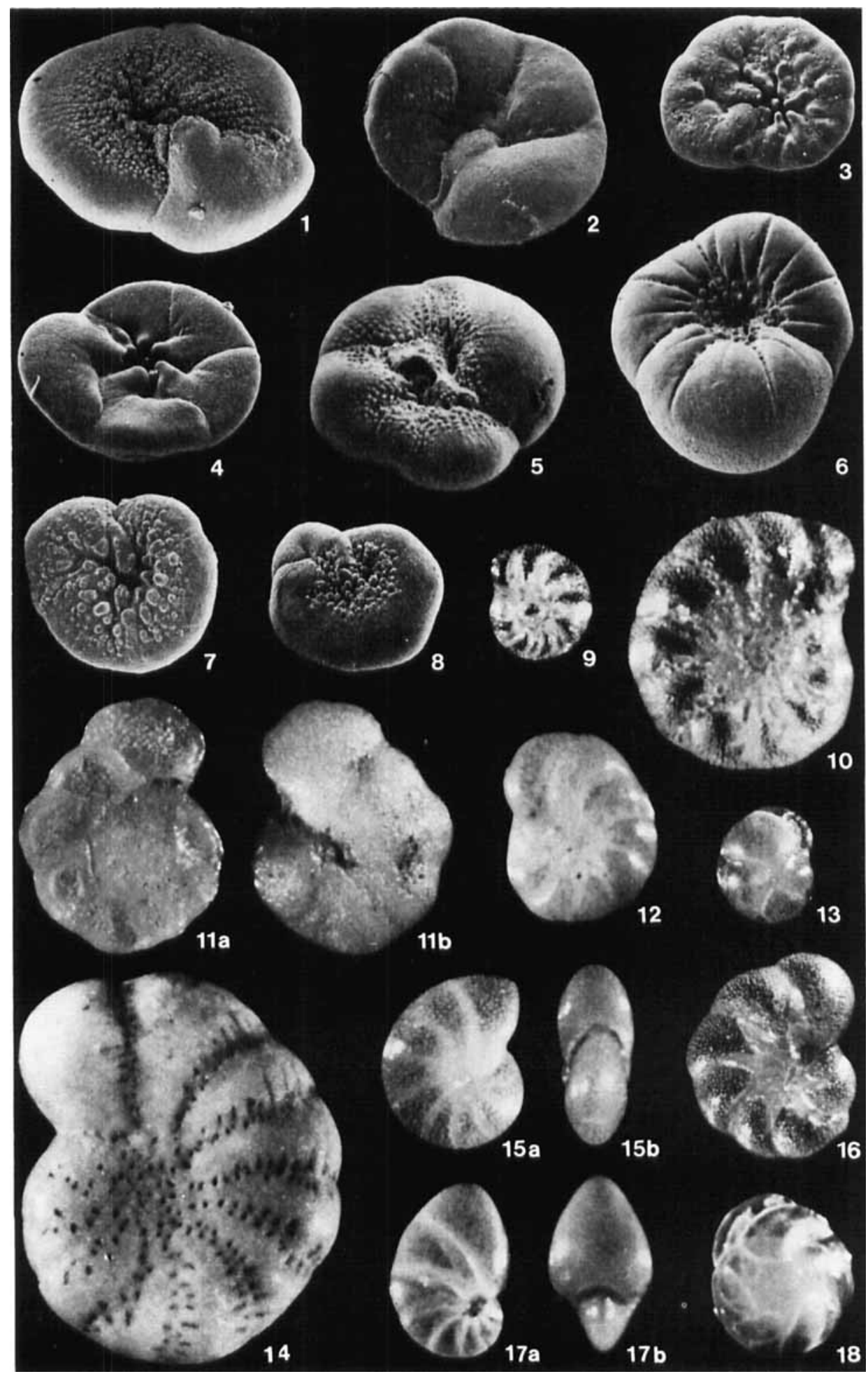




\section{PLATE 4}

\section{DISSOLUTION, BIOLOGICAL BREAK DOWN AND ABRASION}

Fig. 1. Naturally etched specimen of Elphidium excavalum from Cassidulina-Cassidulina assemblage, sample 115/100-110 (A37994); a. overall view, SEM $\times 150$; b. detail of apertural face, SEM $\times 1500$.

Fig. 2. Unetched reference specimen of Elphidium excavalum from Cassidulina-Cassidulina assemblage, sample 116/20-30 (A37995); a. overall view, SEM $\times 150 ;$ b. detail of aperture, SEM $\times 1500$.

Fig. 3. Specimen of Elphidium excavatum soaked in $5 \% \mathrm{H}_{2} \mathrm{O}_{2}$ for 16 hours. From CassidulinaCassidulina assemblage, sample 116/20-30 (A37996); a. overall view, SEM $\times 100$; b. detail of a sutural opening, SEM $\times 1500$.

Fig. 4. Specimen of Elphidium excavatum with signs of solution after 16 hours in $5 \% \mathrm{H}_{2} \mathrm{O}_{2}$ added pyrite. From Cassidulina-Cassidulina assemblage, sample 116/20-30 (A37997); a. overall view, SEM $\times 150$; b. detail of a sutural opening, $\mathrm{SEM} \times 1500$.

Fig. 5. Specimen of Cibicides lobatulus bored by algae. From Cibicides-Rosalina assemblage, sample 66/0-3 (A37998); SEM $\times 50$.

Fig. 6. Specimen of Bucella tenerrima bored by predator. From Cibicides-Rosalina assemblage, sample 66/0-3 (A37999); SEM $\times 150$.

Fig. 7. Broken, unetched specimen of Cibicides lobatulus from Cibicides-Rosalina assemblage, sample 85/0-5 (A38000); SEM $\times 150$. 
PLATE 4

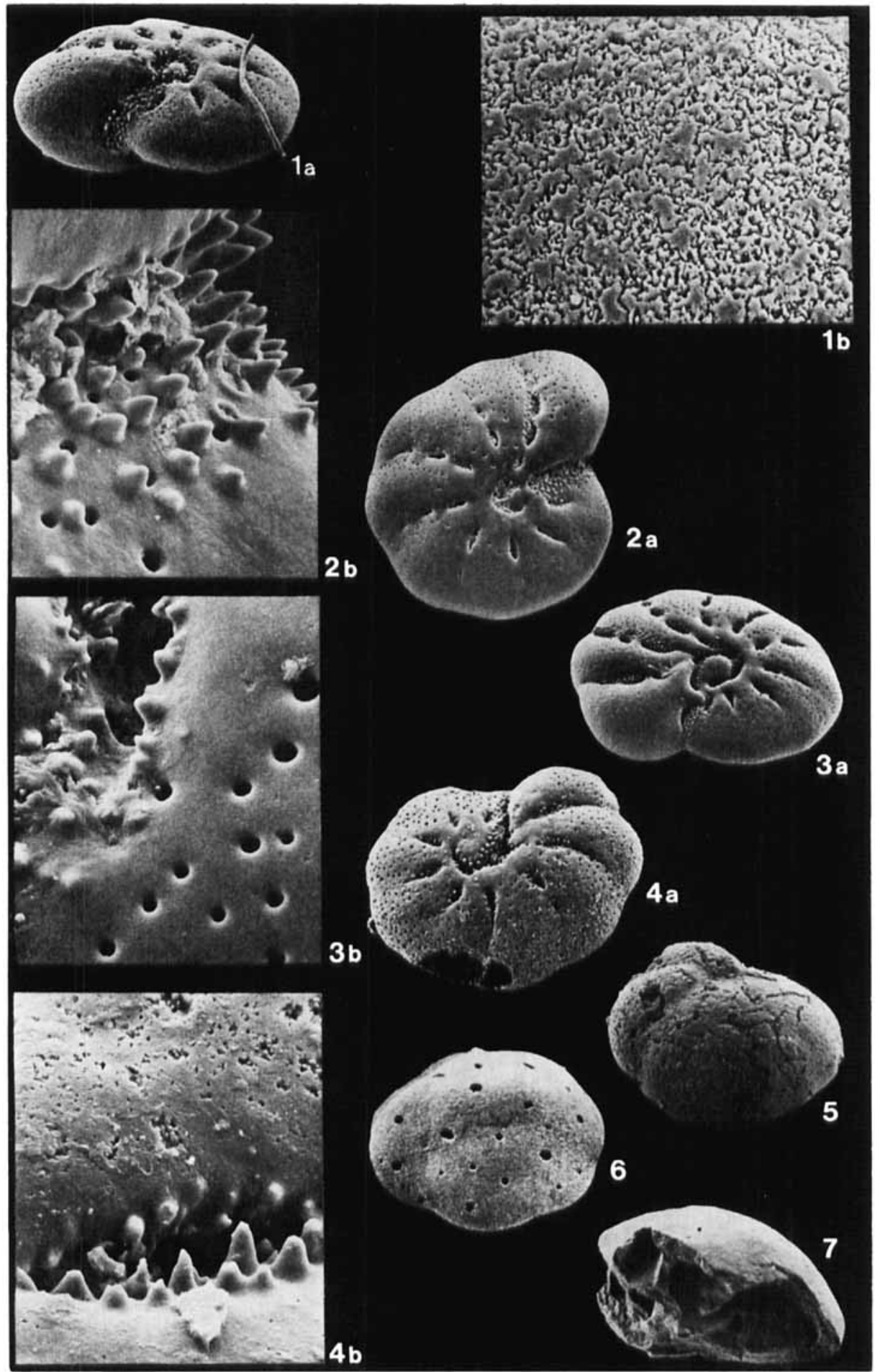


